\title{
An Analysis of Herding in the Korean Stock Market Using Network Theory*
}

\author{
Soosung Hwang, Sungkyunkwan University \\ Young-II Kim, Sungkyunkwan University \\ Jinho Shin, ${ }^{* *}$ Sungkyunkwan University
}

\begin{abstract}
Using network theory, we investigate if investors follow movements of closely 'connected stocks' regardless of their fundamentals or industries when investment decision is driven by panic under stress. We find strong evidence of herding in the Korean market for the period from January 2005 to December 2015 as in previous studies in herding. However, herding arises at positive extreme market movements during bear states. We interpret the results as follows: during bear states when the expected market return is high, overconfident investors over-respond to good signals because the signals are consistent with their priors of the high expected market return (self-attribution bias). Herding does not necessarily arise by panic under stress.
\end{abstract}

Keywords: Herding; Network; Regime Switching; Overconfidence; Connected Stocks

JEL Classification: G01, D85

* We would like to thank the participants at the Allied Korean Finance Association Annual Meeting, Faculty of Economics, Sungkyunkwan University, for their comments on this paper.

** Corresponding Author. Address: College of Economics, Sungkyunkwan University, 25-2 Sungkyunkwan-ro, Jongno-gu, Seoul, Korea, 03063; E-mail: jinho.shinn@gmail.com; Tel: +82-2-3788-2334; Fax: +82-2-3788-2350.

Received 22 August 2017; Revised 29 January 2018; Accepted 15 February 2018 


\section{Introduction}

When investment decision is driven by contagious emotions such as panic, the returns of other stocks may appear to have more information than private information (Banerjee, 1992; Bikhchandani, Hirshleifer, and Welch, 1992; Welch, 1992). This idea of herding has been investigated in the literature at the industrial level by Choi and Sias (2009), Bikhchandani and Sharma (2001), Yao, Ma, and He (2014), Gebka and Wohar (2013), and Demirer, Lien, and Zhang (2015). However, firms are also connected in various other ways, i.e., ownership (Anton and Polk, 2014), liquidity or pairs trading (Shleifer and Vishny, 1992; Gatev, Goetzmann, and Rouwenhorst, 2006; Coval and Stafford, 2007), or firm characteristics (Harvey, Liu, and Zhu, 2016). Herding in small stocks or growth stocks is also reported (e.g., Lakonishok, Shleifer, and Vishny, 1992; Wermers, 1999; Yao, Ma, and He (2014).

Although herding within industries or firm characteristics is itself interesting, these empirical results for specific groups of stocks do not show contagious emotions at the micro level between stocks that are connected in various ways. For example, during the late 1990s when investors pursued high-tech stocks too much regardless of industries or fundamentals, these stock returns co-move, creating bubbles (Hirshleifer and Teoh, 2003). How can we group individual stocks to investigate contagious comovements in returns, which arise by investors herd behavior?

In this study, we investigate herding by grouping individual stocks using network theory rather than by industry or other methods explained above. Our hypothesis is that if investment decision is driven by panic under stress, then investors may follow movements of closely 'connected stocks' regardless of their fundamentals or industries. The analysis of herding using industry classification can be considered as a special case of our study. If market and industry are the only elements that summarize the multi-dimensional facets of connections in individual stocks, then herding we analyze using connected stocks should not be different from that we obtain using industry classification. Otherwise, herding at the market or industry level may not capture investor herd behavior because of various types of connections discussed above.

As our purpose in this study is to investigate herding by coordinated return movements, we focus on contemporaneous relationship in asset returns, and thus apply the minimum spanning tree (MST) proposed by Mantegna (1999) to reduce the complexity of connections in returns between individual stocks.1) We then investigate

1) Herding is broadly defined as the alignment of the thoughts or behaviors of individuals through local interaction and does not necessarily indicate lead-lag relationship (Raafat, Chater, and Frith, 2009), and thus we use the minimum spanning tree that connects individual stocks whose returns move together. For network analysis with directions, i.e., spillover effects in financial markets, see Billio, Getmansky, Lo, and Pelizzon (2012) and Diebold and Yilmaz (2012, 2016). 
whether herd behavior in the equity market is led by a small number of 'core' stocks or by the 'peripheral' stocks connected to these core stocks, both of which are identified using the MST. Test if investors' contagious emotions increase when they are under stress (Christie and Huang, 1995; Chang, Cheng, and Khorana, 2000), we further investigate herd behavior for the periods of bull and bear markets identified with the regime switching model (Hamilton, 1989).

For empirical tests, we choose the Korean stock market to compare our results with those of Chang, Cheng, and Khorana (2000) who find evidence of herding in the Korean market. Analyzing 533 non-securities stocks listed in the Korea Exchange from January 2005 to December 2015, we identify 36 core stocks. The top three core stocks, Keyang Electric Machinery, Hyundai BNG Steel, and Hanjin Heavy Industries and Construction, are connected to 50, 44, and 45 peripheral stocks, respectively. The results seem at odd with our intuition because the largest two firms in the Korean market, Samsung Electronics and Korea Electric Power Corporation, are not identified as core stocks. However, core and peripheral stocks in this study are not identified by lead-lag relationships between individual stocks. As we focus on coordinated return movements to group stocks, core stocks in this study simply represent stocks whose returns are correlated with a larger number of other stocks.

In our main analysis of herding, we exclude securities (brokerage) firms. When these firms are included in the analysis, approximately half of the core stocks are securities firms. This is not surprising because securities firms hold a large amount of other stocks listed in the Korea Exchange and thus their stock returns are closely connected to stocks in other sectors.

Using cross-sectional dispersion in returns as in Christie and Huang (1995) and Chang, Cheng, and Khorana (2000), we find strong evidence of herding at extreme market movements during the entire sample period. When market volatility increases, investors herd and cross-sectional dispersion in returns decreases, i.e., the returns of core stocks come closer to the market return, and those of peripheral stocks also approach the returns of core stocks in their clusters. Our further analysis suggests that herding in the entire period is driven by herding when the market is under stress because herding at extreme market returns arises in bear states rather in bull states. $^{2)}$

However, we find that herding during bear states is observed only when market returns are positive rather than negative. If herding is driven by contagious emotions

2) In bull states, we find evidence of adverse herding. That is, during bull states, cross-sectional dispersion in returns increases and investors do not follow the movements of the market or of core stocks. However, this evidence of adverse herding is found only when securities stocks are included in the analysis. 
such as panic, ${ }^{3)}$ then herding should have arisen at negative and extreme market movements. Our empirical result that herding arises at positive and extreme market movements during bear states does not seem to be explained by the panic driven contagious trading. As an explanation, we propose asymmetry in investor overconfidence to signals (Daniel, Hirshleifer, and Subrahmanyam, 1998, 2001). During bear states when the expected market return is high, overconfident investors over-respond to good signals about market outlook because the signals are consistent with their priors of the high expected market return. When herding is investigated at the industry level, we do not find evidence of herding during bear nor during bull states.

Our contribution to the literature can be summarized as follows. First, we apply network theory to identify connected stocks. Stock returns are the outcome of interactions between investors whose financial decision reflects the characteristics and the behavioral patterns of various entities such as people, groups, and objects, and thus, the equity market has been considered as a complex network (Kelly and Gráda, 2000; Hong et al., 2004). Many attempts have been made for equities, and the recent surge in social network analysis makes it possible to analyze the diverse channels through which researchers approach the topic. ${ }^{4)}$ With the help of network theory we abridge the complex network and identify price co-movements in the equity market effectively.

Second, this paper contributes to the existing research on herding within connected stocks using network theory. We show that stocks grouped using network theory are not necessarily the same as those grouped using the conventional industry classification index. The core stocks are quite different from our intuition, and thus the results on herding are also different from those in the literature. Prior studies on herd behavior use various connections, including investor entities (i.e., individuals, foreigners, and institutions), the aggregate market, and the industrial level. For example, Christie and Huang (1995) investigate herding at the market level whereas Bikhchandani and Sharma (2001), Choi and Sias (2009), Yao, Ma, and He (2014), Gebka and Wohar (2013), and Demirer, Lien, and Zhang (2015) analyze herding at the industry level. Chen (2013) and Chang and Lin (2015) study herding behavior at the international level. On the other hand, some studies investigate herding for groups that are sorted by market capitalization (Chang, Cheng, and Khorana, 2000; Kim, 2013).

Finally, we use a regime switching model to fine bull and bear states and investigate herding in these states. In the literature investors are simply assumed to be under stress when market returns are negative (Christie and Huang, 1995; Chang, Cheng, and Khorana, 2000). However, negative market returns do not always indi-

3) See Bikhchandani and Sharma (2001) and Hirshleifer and Teoh (2003) for the literature review.

4) See, for example, Boyd and Ellison (2007). 
cate that investors are under stress. If herding increases when investors are under stress and their decisions are driven by panic behavior (Bikhchandani and Sharma, 2001; Demirer, Lien, and Zhang, 2015), it should happen when market returns are negative in bear states not in bull states. Our results do not support this panic driven herding. Instead we find evidence of herding in bear states when market returns are large and positive.

In this study, we analyze herding from a different (network) perspective, and could not propose a method to differentiate between rational and irrational herding. The majority of studies investigate herding by observing the clustering behavior of market experts such as analysts or institutional investors (see Welch, 2000; Barber, Odean, and Zhu, 2009; Choi and Sias, 2009; Hirshleifer and Teoh, 2009) or find some evidence in emerging markets such as South Korea and Taiwan (Chang et al., 2000). More recently, Cipriani and Guarino (2014) demonstrate that informed traders herd to a significant degree in their high-frequency trading. These empirical results, however, do not necessarily indicate that asset prices are biased such that the efficient allocation of assets is disturbed. We leave for future study if the market becomes inefficient due to herding between connected stocks.

This paper is organized as follows. In the following section, we describe how to construct the MST using Kruskal's (1956) algorithm and how to test herding using the network identified by the algorithm. In Section 3, we present the properties of core and peripheral stocks and report the empirical results for herding. Section 4 concludes our paper.

\section{Networks in the Stock Market and Herding}

In this section we first explain how to identify core and peripheral stocks using network theory and then propose testable models for the analysis of herd behavior.

\subsection{Analysis of Network and Clusters}

There are various methods to group stocks. A popular method in the herding literature is industry classification because investors' signals, financial analysts' recommendations, and managers' business decisions are often at the industry level (Choi and Sias, 2009; Bikhchandani and Sharma, 2001; Yao, Ma, and He, 2014; Gebka and Wohar, 2013; Demirer, Lien, and Zhang, 2015). ${ }^{5}$ In the studies of herding, grouping stocks using industry classification is appealing because investors who are under se-

5) Others investigate herding at the international level because of the globalization of financial markets (Gebka and Wohar, 2013; Chen, 2013; Chang and Lin, 2015). 
vere stress may erroneously believe that the price changes of other stocks in the same industry have more information than their private information (Banerjee, 1992; Bikhchandani, Hirshleifer, and Welch, 1992; Welch, 1992).

However, in asset pricing, it is well documented that various firm characteristics size, book-to-market, liquidity, and growth-also matter and thus have been used to form groups of stocks for which investors face similar pricing problems.6) These may be due to trading (Shleifer and Vishny, 1992; Gatev, Goetzmann and Rouwenhorst, 2006; Coval and Stafford, 2007) or ownership (Anton and Polk, 2014). Asset returns may also be connected between firms that have a vertical relationship or are owned by the same business family.

These complex dimensions of connections between stocks can be effectively abridged using network theory. Networks have been investigated in various fields of studies. Examples in finance include studies in stock markets (Mantegna, 1999; Onnela et al., 2003b; Ahn, Conrad, and Ditmmar, 2009; Kenett et al., 2010; Kenett et al., 2010), foreign exchange markets (Naylor, Rose and Moyle, 2007), or volatility (Diebold and Yilmaz, 2016). Others include studies in the areas of the World Wide Web and Internet (Dorogovtsev, Mendes, and Samukhin, 2003), social network (Scott, 2013), and citation network analysis (Batagelj, 2003). These studies report that the network between elements has topological properties distinct from that of a regular or random graph.

Among various methods have been proposed to analyze financial markets, ${ }^{7)}$ we use a simple but popular method to construct a network between stocks: the asset tree introduced by Mantegna (1999) using the minimum spanning tree (MST). The MST method has merits that it satisfies the standard axioms of the Euclidean metric without losing too much information in the network and thus conserves most network properties (Cormen, Leiserson, Rivest, and Stein, 2009). Moreover, this method uses correlation coefficients between individual stock returns to construct a network, which is intuitively appealing. Our MST method, however, does not consider any lead-lag relationship between stocks, because we focus on co-movement in asset returns to identify connected stocks. ${ }^{8}$

6) For example, see Harvey, Liu, and Zhu (2016) for a literature survey for numerous methods to form portfolios using firm characteristics that have been identified in empirical studies.

7) Examples include non-linearity in connection (Onnela et al., 2003a), distance matrices with Gower's metric distance (Tumminello, Aste, Di Matteo, and Mantegna, 2005), single linkage cluster analysis and average linkage cluster analysis (Tumminello, Lillo, and Mantegna, 2010), the partial correlation threshold network (Kenett, Tumminello, and Madi, 2010), and generalized variance decomposition (Diebold and Yilmaz, 2012).

8) Recently, Diebold and Yilmaz $(2012,2016)$ propose a method that integrates directions in the network in order to analyze trans-Atlantic volatility spillover during the 2008 crisis. 
To generate the MST, we first calculate distance between stocks using a Spearman's rank correlation coefficient $\left(\rho_{i j}\right):{ }^{9)}$

$$
d_{i j}=1-\left|\rho_{i j}\right|
$$

where $i$ and $j$ denote individual stocks $i$ and $j$, respectively. The distance measure treats positive and negative correlations in the same way because a negatively correlated asset can be turned into a positively correlated asset by taking short positions. ${ }^{10}$ Note that our network does not change for any non-linear function of $\left|\rho_{i j}\right|$ as far as $d_{i j}$ monotonically decreases as $\left|\rho_{i j}\right|$ increases. The distance measure ranges from 0 to 1 and shows less correlation as its value approaches 1 . When there are $N$ individual stocks, $N(N-1) / 2$ distances are calculated.

The distances are then used to construct the MST using Kruskal's (1956) algorithm. Kruskal's algorithm finds a subset of the distances and forms a tree that includes every stock. It connects individual stocks in an effective way because the total weight of all the distances in the tree is minimized. More specifically, the MST method forms a network by sequentially selecting non-circular links with the shortest distance among $N(N-1) / 2$ number of links such that the $N(N-1) / 2$ correlations or distances can be reduced to $N-1$ links that have the shortest distance. For example, when $N=$ 1,000, we have approximately half a million links (correlations) to be analyzed, which become 999 links using the MST algorithm.

Kruskal's algorithm allows us to divide individual stocks into a certain number of coherent groups so that the minimum distance between stocks in different groups is maximized. However, there are no specific criteria for grouping and thus we identify core stocks if the following condition is satisfied: a core stock should have at least $K$ directly or indirectly linked peripheral stocks and have at least one link to other core stocks. Therefore, every stock is linked in the MST, and a bridged core stock (that exists between two core stocks) and its peripheral stocks can be grouped into a separate cluster.

The minimum number $K$ of peripheral stocks linked to a core stock should be defined considering the number of clusters, i.e., the number of core stocks out of the total number of stocks $(N)$. For example, if $K$ is too large with respect to $N$, the number

9) Spearman correlations are used in this study instead of Pearson correlations because of the non-normality of stock returns.

10) Moreover, most stocks are positively correlated and thus the MST constructed using $1-\rho_{i j}$ as a distance measure is similar to what we report in this study. Note that our distance measure is not exactly the same as the one used by Mantegna (1999). 
of core stocks decreases and the clusters may include less connected stocks. On the other hand, if $K$ is too small, the number of clusters increases so much that stocks may belong to different clusters even if they are linked. In these cases, our network analysis would not be useful for the investigation of herding in connected stocks. We initially set $K$ such that the number of clusters is close to the number of industries for comparison purpose and then perform robustness tests by changing $K{ }^{11)}$

\subsection{Herd Measure and Cross-Sectional Dispersion of Returns}

We investigate herding in connected stocks under the assumption that stocks with close connections are more affected by investor herding than those grouped by other grouping methods. If investors observe and follow movements of closely connected stocks suppressing their own private information, the prices of connected stocks are likely to co-move regardless of their fundamentals. Therefore, as argued by Christie and Huang (1995), the magnitude of cross-sectional dispersion of individual stock returns decreases during large price changes when investors follow the observed decisions of others rather than their own beliefs and information. ${ }^{12)}$

To investigate whether herding arises in core stocks and/or peripheral stocks, we first define cross-sectional variance (CSV) in returns as follows:

$$
\mathrm{CSV}=E\left[\left(r_{i t}-r_{m t}\right)^{2}\right]
$$

where $r_{i t}$ and $r_{m t}$ denote returns of stock $i$ and the market at time $t$, respectively. The CSV can then be decomposed into CSVs in core and peripheral stocks, as follows:

$$
\begin{aligned}
& \operatorname{CSV}^{P}=E\left[\left(r_{i t}-r_{c i t}\right)^{2}\right], \\
& C S V^{C}=E\left[\left(r_{c i t}-r_{m t}\right)^{2}\right],
\end{aligned}
$$

Where $\operatorname{CSV}^{P}$ is the cross-sectional variance of peripheral stocks with respect to core stocks $\left(r_{c i t}\right)$ and $\mathrm{CSV}^{C}$ is the cross-sectional variance of core stocks with respect to the market $\left(r_{m t}\right)$.

11) The network itself does not change regardless of the minimum number of peripheral stocks linked to a core stock, and thus $K$ cannot be optimized.

12) Various measures have been proposed to investigate herd behavior in financial markets. Lakonishok, Shleifer, and Vishny (1992) base their criterion on the trades conducted by a subset of market participants over a period of time. Wermers (1999) proposes a portfolio-change measure designed to capture both the direction and intensity of trading by investors. However, these measures do not directly show the effects of herding on asset prices. 
For consistency with other previous studies, cross-sectional dispersion is measured by cross-sectional standard deviations rather than cross-sectional variance. Crosssectional dispersions (CSDs) are defined as follows:13)

$$
\begin{gathered}
\mathrm{CSD}_{t}=\sqrt{\frac{1}{N-1} \sum_{i=1}^{N}\left(r_{i t}-r_{m t}\right)^{2}}, \\
\mathrm{CSD}_{t}^{P}=\sqrt{\sum_{c i=1}^{N_{c}} w_{c i} \frac{1}{N_{c i}} \sum_{i=1}^{N_{c i}}\left(r_{i t}-r_{c i t}\right)^{2}}, \\
\mathrm{CSD}_{t}^{C}=\sqrt{\sum_{c i=1}^{N_{c}} w_{c i}\left(r_{c i t}-r_{m t}\right)^{2}},
\end{gathered}
$$

where $N_{c}$ and $N_{c i}$ represent the numbers of core stocks and the peripheral stocks linked to a core stock $c$, respectively, and $w_{c i}=\frac{N_{c i}}{N}$. When industry is used for grouping, $r_{c i t}$ is replaced with equally weighted industry returns.

\subsection{Empirical Models for Testing Herd Behavior in the Equity Market}

If investors' tendency to follow the market consensus increases when they are under stress (Christie and Huang, 1995; Chang, Cheng, and Khorana, 2000), then the cross-sectional dispersion decreases with the market volatility. To investigate this, Christie and Huang (1995) regress cross-sectional dispersions in returns on an intercept and two dummy variables designed to capture extreme positive and negative market returns. Negative coefficients on the dummy variables can be interpreted as evidence of herding. ${ }^{14)}$

In this study, we test this type of herding using the following regression:

$$
\begin{aligned}
\mathrm{CSD}_{t}= & \gamma_{0}+\gamma_{1}^{+}\left|r_{m t}\right| I_{r_{m t} \geq 0}+\gamma_{1}^{-}\left|r_{m t}\right|\left(1-I_{r_{m t} \geq 0}\right) \\
& +\gamma_{2}^{+} r_{m t}^{2} I_{r_{m} \geq 0}+\gamma_{2}^{-} r_{m t}^{2}\left(1-I_{r_{m t} \geq 0}\right)+\varphi \mathrm{CSD}_{t-1}+\varepsilon_{t}
\end{aligned}
$$

where $\varepsilon_{t}$ is an error term, and $I_{r_{m t} \geq 0}$ equals one when the market return is positive or zero and zero otherwise. The lagged $\mathrm{CSD}_{t-1}$ is used as an explanatory variable because of the persistence of $\mathrm{CSD}_{t}$. The coefficients on the absolute market return are expected to be positive, i.e., $\gamma_{1}^{+}>0$ and $\gamma_{1}^{-}>0$, because of a close association between market volatility and cross-sectional dispersion in returns (Christie and Huang, 1995; Hwang and Satchell, 2005). In this regression, we expect both $\gamma_{2}^{+}$and $\gamma_{2}^{-}$to be negative if

13) See the Appendix for the details of the equations.

14) The results with Christie and Huang's (1995) method, which are reported later in the robustness tests, are not different from the main results. 
investors follow others during large market movements. In particular, if investors herd more strongly in response to bad signals than to good signals (Peeters and Czapinski, 1990; Baumeister et al., 2001), we expect $\gamma_{2}^{-}<\gamma_{2}^{+}<0$ : i.e., herding to sell is stronger than herding to buy.

Herding may increase when investors are under stress (Bikhchandani and Sharma, 2001; Demirer, Lien, and Zhang, 2015). In the literature investors are simply assumed to be under stress when market returns are negative (Christie and Huang, 1995; Chang, Cheng, and Khorana, 2000). However, negative market returns in bull markets do not necessarily lead to investors' panic behavior. Panic-driven herding is more likely to happen when market returns are negative during bear markets rather than bull markets.

Therefore, we investigate herding in different market states, i.e., bull and bear states. Motivated by the regime switching literature (e.g., Hamilton, 1989), we identify bull and bear states using the following simple regime switching model:

$$
\begin{aligned}
& r_{m t}=\mu_{1} S_{1 t}+\mu_{2} S_{2 t}+\sigma_{t} \varepsilon_{t}, \\
& \sigma_{t}=\sigma_{1} S_{1 t}+\sigma_{2} S_{2 t},
\end{aligned}
$$

where $r_{m t}$ is the market return, $\mu_{i}$ and $\sigma_{i}$ are the expected market return and volatility of regime $i=1,2$, respectively, and the dummy (state) variable $S_{i t}$ is one when regime $i$ is selected and zero otherwise. As in Hamilton (1989), the state variables are assumed to be governed by a first-order Markov chain. The regime switching model is estimated using the Markov Chain Monte Carlo Gibbs sampling estimation. ${ }^{15)}$ Once the two states are identified, they are named 'bull' and 'bear' states according to the characteristics of the expected market return and volatility.

The difference in herding between bull and bear states can be tested using the following regression equation:

$$
\begin{aligned}
\mathrm{CSD}_{t}= & \gamma_{0}+\gamma_{1 u}^{+}\left|r_{m t}\right| I_{r_{m t} \geq 0} I_{u t}+\gamma_{1 u}^{-}\left|r_{m t}\right|\left(1-I_{r_{m t} \geq 0}\right) I_{u t} \\
& +\gamma_{1 d}^{+}\left|r_{m t}\right| I_{r_{m t} \geq 0}\left(1-I_{u t}\right)+\gamma_{1 d}^{-}\left|r_{m t}\right|\left(1-I_{r_{m t} \geq 0}\right)\left(1-I_{u t}\right) \\
& +\gamma_{2 u}^{+} r_{m t}^{2} I_{r_{m t} \geq 0} I_{u t}+\gamma_{2 u}^{-} r_{m t}^{2}\left(1-I_{r_{m t} \geq 0}\right) I_{u t} \\
& +\gamma_{2 d}^{+} r_{m t}^{2} I_{r_{m t} \geq 0}\left(1-I_{u t}\right)+\gamma_{2 d}^{-} r_{m t}^{2}\left(1-I_{r_{m t} \geq 0}\right)\left(1-I_{u t}\right)+\varphi \mathrm{CSD}_{t-1}+\varepsilon_{t},
\end{aligned}
$$

15) The standard conjugate Gaussian distribution and the inverted gamma distribution are used for $\mu_{i}$ and $\sigma_{i}$, respectively, as described by Zellner (1971). We use conjugate beta priors to estimate the transition probabilities, but to avoid regimes changing too frequently, stronger priors are given to the probabilities such that the same state continues in the next period. The strong persistence of regimes, however, does not mean that returns are highly autocorrelated. It suggests that regimes are highly likely to stay in the same regime over time. All results are generated with 10,000 iterations after at least 10,000 burn-in iterations. For detailed explanations, see Kim and Nelson (1999). 
where $I_{u t}$ equals one in the bull state (the probability of the bull state is larger than 0.5 ) and zero otherwise. In general, negative coefficients on $r_{m t}^{2}$ suggest herding. If herding intensifies when the market goes down in bear states, we expect a large negative coefficient $\bar{\gamma}_{2 d}$. Equations (7) and (9) are estimated for $\mathrm{CSD}_{t}, \mathrm{CSD}_{t}^{P}$, and $\mathrm{CSD}_{t}^{C}$ for herding in the entire market, peripheral stocks, and core stocks, respectively.

\section{Empirical Analysis}

We investigate herd behavior in the Korean stock market using the network identified by the MST and compare the results with those of Chang, Cheng, and Khorana (2000) who find evidence of herding in the Korean market. The Korean stock market is characterized by active individual investors: their trading volume in 2016 consists of $66 \%$ of the total trading although their equity holding proportion is just $20 \%$. ${ }^{16}$ ) The large trading volume of individual investors suggests that stock prices in the Korean market are likely to be affected by behavioral biases by these noisy investors.

Daily returns of 558 common stocks listed in the Korea Exchange are used for the sample period from January 2005 to December 2015.17) For robustness of our results, we use three different networks: network estimated with all stocks, network estimated with stocks excluding securities firms, and 24 industries classified by the Korea Exchange using the Global Industry Classification Standard (GICS). ${ }^{18)}$ Our data source is Datastream. Equal weight is used to calculate the market and the index returns because CSDs are not value weighted.

\subsection{Network Structure of the Korean Stock Market}

We calculate the Spearman rank correlation matrix of the 558 stocks to obtain the network of the Korean stocks. The network is composed of 558 nodes and 557 links. In $<$ Figure $1>$, connections between stocks are visualized using a program called Pajek, where individual stocks (nodes) are located on the circle and their connections with other stocks are expressed with straight lines. We present three cases for comparison: 1) the connection between stocks is random (panel A), 2) all stocks in the market (panel B), and 3) non-securities stocks (panel C). For the first case in panel A,

16) Korea Exchange, DataGuide.

17) The Spearman's rank correlation coefficient in equation (1) is estimated using the entire sample. We implicitly assume that investors are concerned about the returns of stocks that are connected over a longterm period. Considering that correlation changes over time (Campbell, Lettau, Malkiel, and Xu, 2001), however, the entire sample period could be divided into multiple sub-sample periods to investigate changes in the network. We leave this for future study.

18) We also test 17 industries that have at least five stocks. The results are not different from those reported with the 24 industries. 
An Analysis of Herding in the Korean Stock Market Using Network Theory

the correlation coefficients between stocks are generated randomly and thus do not show any pattern (concentration) in the connection. The connection of random correlations generated by Pajek spans equally among stocks and has no pattern. However, when one stock is connected to others more than any other stocks in the entire network, the stock has the largest number of links. This is the case in panels B and C we have estimated using the 558 stocks and 533 non-securities stocks, respectively. As in the previous literature, the topological properties of the connections are distinct from that of the random network in panel $\mathrm{A}$, because they visualize many core stocks. The connections with all stocks show concentration to a smaller number of core stocks many of which are securities stocks.

\section{〈Figure 1〉 Network Visualization}

The network in the stock market is visualized with circle graphs using Pajek, a program for large network analysis. In a circle graph, the stocks (nodes) are located at equal distances around the circle, and highly connected stocks can be easily visualized because of the density of lines that are connected other stocks. The first figure shows a network when the correlation coefficients between stocks are generated in a random way and thus there is no clear pattern. The second and third figures represent networks of all stocks and stocks excluding securities firms, respectively.

A: Random Network

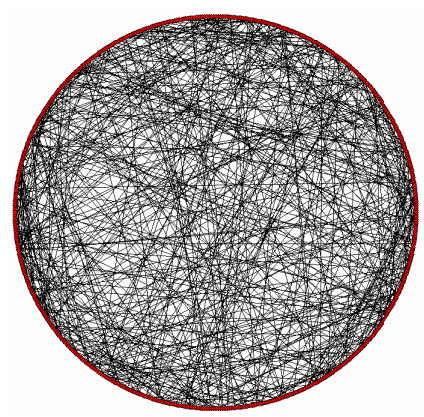

B: Network with All Stocks

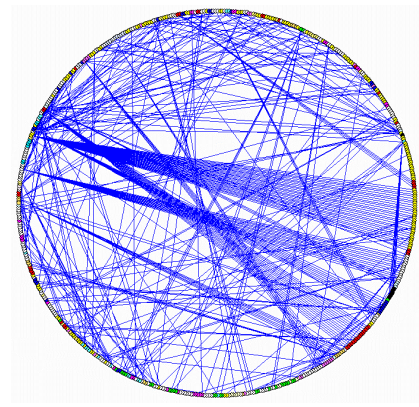

C: Network with non-Securities Stocks

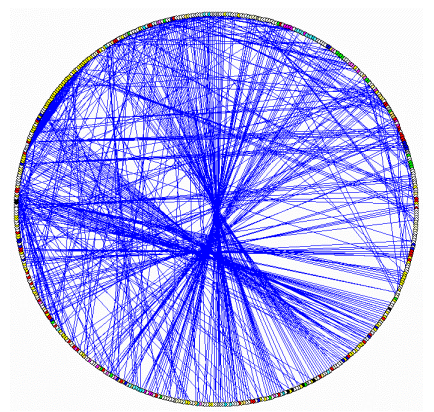

We create clusters with $K=6$ so that at least six peripheral stocks are connected to a core stock. The number of core stocks identified by these criteria is $5 \sim 6 \%$ of all stocks, which is close to the number of industries. <Table $1>$ shows clusters and their core stocks sorted by the numbers of links in the clusters. When all stocks are included in the network analysis, there are 28 clusters (core stocks), 11 of which are securities firms whose performance depends on that of other stocks in the stock market. ${ }^{19)}$ The

19) This result is consistent with the literature on the Korean stock market network, for example, Lee and Woo (2013) who find that the top four out of 15 stocks that have a large influence in the Korean stock market are securities firms. 
top five clusters include 233 stocks, and the 28 clusters include 530 stocks. When the securities firms are excluded, more clusters, 36 , are found but the number of peripheral stocks in each of the clusters decreases so that 497 stocks are included in the 36 clusters. ${ }^{20}$ )

\section{〈Table 1〉 Clusters and Core Stocks}

This table shows the core stocks and the number of peripheral stocks in each core stock (cluster) identified by the MST and the heuristic method that requires at least 6 peripheral stocks connected to a core stock. Panel A reports 28 clusters identified using all stocks and Panel B shows 36 clusters when securities firms are excluded.

\begin{tabular}{|c|c|c|c|}
\hline & Core Stocks & $\begin{array}{c}\text { Number of } \\
\text { directly linked } \\
\text { peripheral } \\
\text { stocks }\end{array}$ & $\begin{array}{c}\text { Number of total } \\
\text { peripheral } \\
\text { stocks }\end{array}$ \\
\hline \multicolumn{4}{|c|}{ A: Network with All Stocks } \\
\hline Cluster1 & Dongbu Securities Co., Ltd. & 50 & 74 \\
\hline Cluster2 & Kdb Daewoo Securities Co. & 33 & 64 \\
\hline Cluster3 & Sk Securities Company Limited & 24 & 36 \\
\hline Cluster4 & Hyundai Securities Company Limited & 20 & 26 \\
\hline Cluster5 & Hanwha Investment \& Securities Company Limited & 19 & 33 \\
\hline Cluster6 & Hyundai Bng Steel Co Ltd & 17 & 20 \\
\hline Cluster7 & Samsung Securities Company Limited & 13 & 24 \\
\hline Cluster8 & Yuanta Securities Korea Co., Ltd & 11 & 19 \\
\hline Cluster9 & Keyang Electric Machinery Company & 10 & 12 \\
\hline Cluster10 & Hanjin Heavy Ind \& Const Holdings & 9 & 16 \\
\hline Cluster11 & Doosan Infracore Company Limited & 8 & 16 \\
\hline Cluster12 & Korea Investment Holdings Company & 8 & 13 \\
\hline Cluster13 & Hmc Investment Securities Company & 7 & 6 \\
\hline Cluster14 & Daishin Securities Company Limited & 7 & 6 \\
\hline Cluster15 & Nh Investment \& Securities Co Ltd & 7 & 12 \\
\hline Cluster16 & Seoyon Co Ltd & 7 & 13 \\
\hline Cluster17 & Hyundai Steel Co & 6 & 15 \\
\hline Cluster18 & Hyundai Motor Company Limited & 6 & 7 \\
\hline Cluster19 & Taekwang Industrial Company & 6 & 13 \\
\hline Cluster20 & Daelim Industrial Company Limited & 6 & 8 \\
\hline Cluster21 & Chongkundang Holdings Corp & 6 & 10 \\
\hline Cluster22 & Tongyangmoolsan Co Ltd & 6 & 6 \\
\hline Cluster23 & Dong Wha Pharm Company Limited & 5 & 14 \\
\hline Cluster24 & Yungjin Pharmaceutical Company & 5 & 11 \\
\hline Cluster25 & Gs Engineering \& Construction Corp & 5 & 12 \\
\hline Cluster26 & Ni Steel Company Limited & 4 & 17 \\
\hline Cluster27 & Lotte Chemical Corp & 5 & 20 \\
\hline Cluster28 & Hanyang Securities Co., Ltd. & 6 & 7 \\
\hline
\end{tabular}

20) When 25 securities stocks are excluded, the total number of stocks becomes 533 . 
$\langle$ Table 1〉 Clusters and Core Stocks (Continued)

\begin{tabular}{|c|c|c|c|}
\hline & Core Stocks & $\begin{array}{l}\text { Number of } \\
\text { directly linked } \\
\text { peripheral } \\
\text { stocks }\end{array}$ & $\begin{array}{l}\text { Number of total } \\
\text { peripheral } \\
\text { stocks }\end{array}$ \\
\hline \multicolumn{4}{|c|}{ B: Network with Non-securities Stocks } \\
\hline Cluster1 & Keyang Elec.Mch. & 32 & 50 \\
\hline Cluster2 & Hyundai Bng Steel & 29 & 44 \\
\hline Cluster3 & Hanjin Hvind. \& Con.Hdg. & 20 & 45 \\
\hline Cluster4 & Hansol Logistics & 12 & 23 \\
\hline Cluster5 & Daou Technology & 10 & 17 \\
\hline Cluster6 & Hankuk Carbon & 10 & 9 \\
\hline Cluster7 & Doosan Infracore & 9 & 15 \\
\hline Cluster8 & Doosan Engr. \& Con. & 8 & 11 \\
\hline Cluster9 & Seoyeon & 7 & 9 \\
\hline Cluster10 & Dong Wha Pharm. & 7 & 17 \\
\hline Cluster11 & Daelim Industrial & 7 & 11 \\
\hline Cluster12 & Gs Engr. \& Con. & 7 & 14 \\
\hline Cluster13 & Tong Yang Moolsan & 7 & 6 \\
\hline Cluster14 & Hanwha & 7 & 8 \\
\hline Cluster15 & Hwashin & 6 & 8 \\
\hline Cluster16 & Kb Financial Group & 6 & 15 \\
\hline Cluster17 & Chongkundang & 6 & 7 \\
\hline Cluster18 & Lg Life Sciences & 6 & 6 \\
\hline Cluster19 & Samsung C \& T & 6 & 14 \\
\hline Cluster20 & Hyundai Heavy Industries & 6 & 6 \\
\hline Cluster21 & K C Tech & 6 & 8 \\
\hline Cluster22 & Sam Young Eltn. & 6 & 13 \\
\hline Cluster23 & Hanwha Chemical & 6 & 13 \\
\hline Cluster24 & Lotte Chemical & 6 & 21 \\
\hline Cluster25 & Taekwang Indl. & 6 & 9 \\
\hline Cluster26 & Hyundai Steel & 6 & 12 \\
\hline Cluster27 & Moonbae Steel & 6 & 6 \\
\hline Cluster28 & Posco & 6 & 12 \\
\hline Cluster29 & Ni Steel & 4 & 11 \\
\hline Cluster30 & Hyundai Marine \& Fire In. & 5 & 7 \\
\hline Cluster31 & Willbes \& Company & 5 & 10 \\
\hline Cluster32 & Lotte Chilsung & 5 & 6 \\
\hline Cluster33 & Bukwang Pharmaceutical Ind & 5 & 9 \\
\hline Cluster34 & Kwang Dong Pharm. & 5 & 11 \\
\hline Cluster35 & Hansol Technics & 5 & 8 \\
\hline Cluster36 & Mirae & 5 & 6 \\
\hline
\end{tabular}




\section{〈Figure 2〉 Network}

The figures show network identified with the Minimal Spanning Tree and the heuristic method for clustering (A core stock has at least 6 directly linked peripheral stocks, a core stock that has at least one link to another core stock, and a bridge stock (that exists between two core stocks) that has at least 6 directly or indirectly linked to peripheral stocks).

A: Network with All Stocks

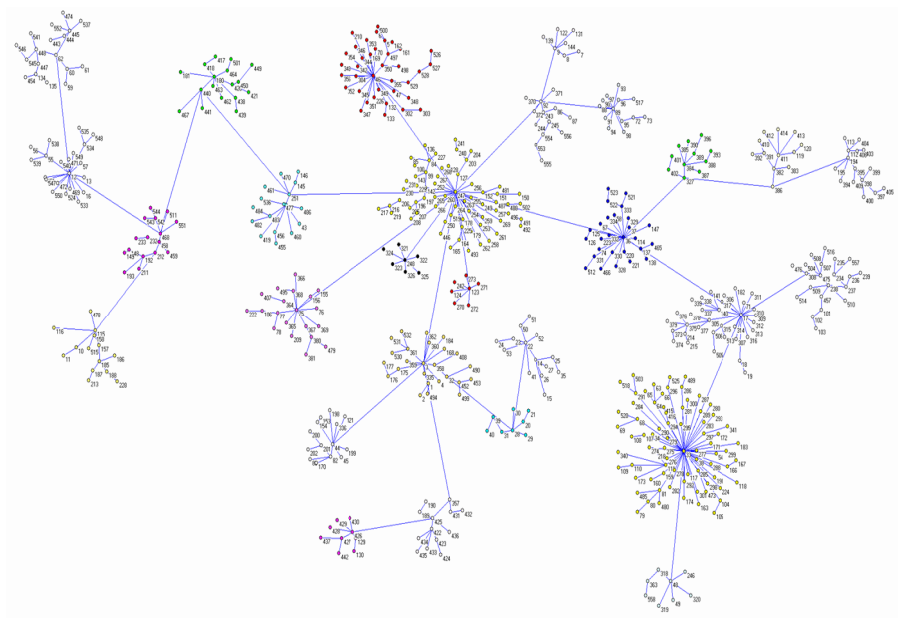

B: Network with non-Securities Stocks

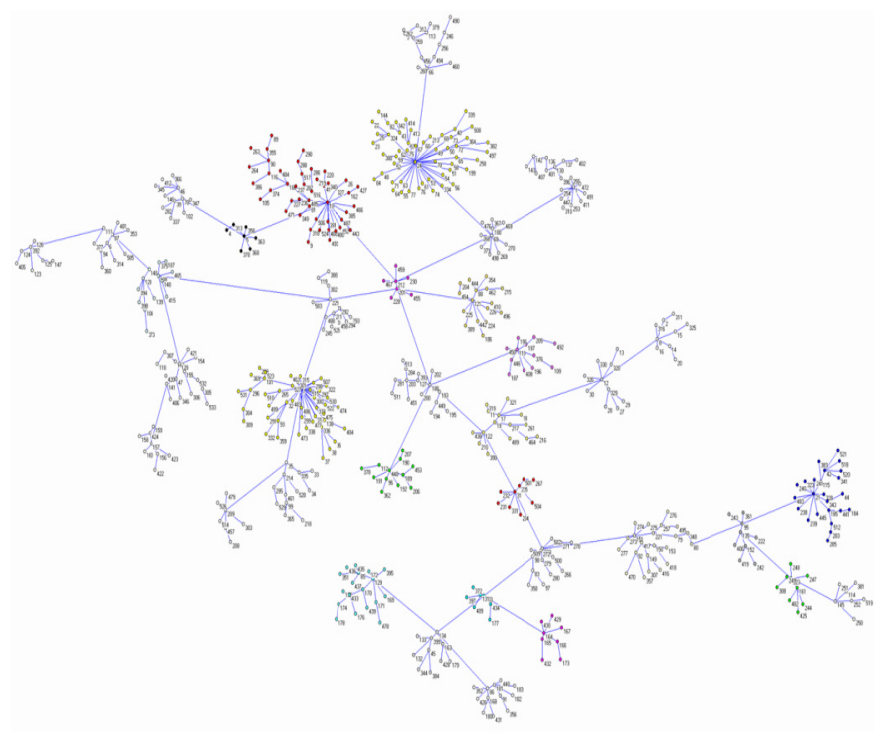

These results are summarized in $<$ Figure $2>$, where the connections between stocks using the MST are visualized. The first figure for the network with all stocks shows that Dongbu Securities and KDB Daewoo Securities are the cores of the two largest 
An Analysis of Herding in the Korean Stock Market Using Network Theory

clusters, which include 74 and 64 stocks, respectively (<Table 1>). The second figure for the network with non-securities stocks shows that concentration to the largest few clusters is less severe.

$<$ Figure 3> depicts the number of peripheral stocks included in each of the clusters. The shape of this link distribution suggests a power law distribution and is consistent with the previous studies that stock markets belong to a scale-free network (Garlaschelli et al., 2005). For example, the results with non-securities stocks show that most stocks have weak relations with others because 336 out of 533 (63\%) stocks have a single link and 90 (17\%) stocks have two links, whereas the top three clusters have 139 peripheral stocks.

\section{〈Figure 3〉 The distribution of links}

The network distributions represent the number of peripheral stocks included in each of the clusters in the descending order. In an extreme case where there is no connection, the number of clusters is equivalent to the number of stocks in the sample.

A: Network with All Stocks

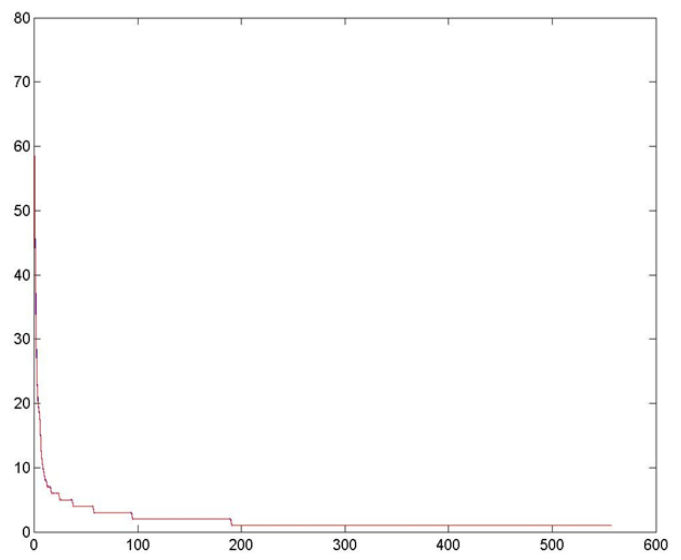

B: Network with non-Securities Stocks

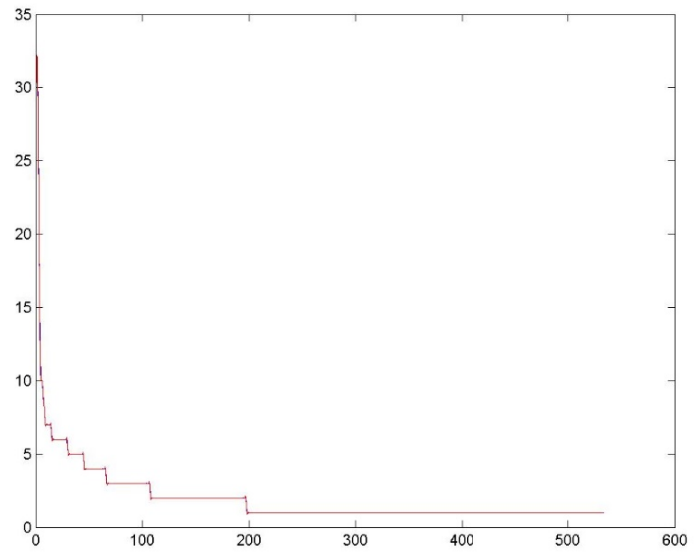

It is interesting that the core stocks identified with non-securities stocks do not include the largest stocks such as Samsung Electronics or Korea Electric Power Corporation. These largest stocks do not necessarily have more links with other stocks in the market despite their importance (weights) in the market return. In fact, the network analysis shows us that medium size stocks such as Keyang Electric Machinery, Hyundai BNG Steel, and Hanjin Heavy Industries and Construction are the top three core stocks that have 139 stocks in their clusters. It is worth noting that the links simply show strong cross-correlation in returns between these medium size stocks and other peripheral stocks connected to them. The links do not suggest that these medium size stocks lead the peripheral stocks. Having said that, it is surprising to 
find that medium size stocks are connected to other stocks more than the largest two stocks in the market.

\subsection{Estimation of Market States and Properties of Cross-Sectional Dispersion}

In this subsection, we investigate the properties of cross-sectional dispersions in different market states for the core and peripheral stocks identified in the previous subsection. Herding is expected to increase when investors process information under stress (Schwert, 1990; Christie and Huang, 1995; Chang, Cheng, and Khorana, 2000; Brunnermeier, 2001).

We first identify market states using the regime switching model in (8). ${ }^{21)}$ The estimation results for the equally weighted market return without securities stocks show clear difference in regimes. ${ }^{22}$ ) The average daily returns (standard deviations) of the two regimes are $0.096 \%(1.22 \%)$ and $-0.158 \%(1.64 \%)$. The first regime can be interpreted as bull states because of its higher average return and lower volatility, whereas the second regime represents bear states because of its lower average return and higher volatility. The probability of the bull states is $76.3 \%$, suggesting that bull states dominate Korean stock market during the sample period.

$<$ Figure $4>$ reports the smoothed probabilities of the two market regimes. Bear states are identified during the financial crisis in 2008 and 2009, the late 2011, and intermittently in 2006, 2007, and 2015. Panel B of < Table $2>$ reports summary statistics of regimes when the smoothed probabilities that are larger than 0.5 are used to identify market states. ${ }^{23)}$ The number of days in bear states is 512 , and the average daily return and standard deviation of the market return are $-0.26 \%$ and $2.26 \%$, respectively. In general, bull periods are far more frequent: the number of days in bull states is 2,218 . The average daily return and standard deviation of the market return during the bull state are $0.11 \%$ and $0.76 \%$, respectively. Investors (markets) are under stress when market returns are negative and volatility is high (in bear states).

21) The standard conjugate Gaussian distribution and the inverted gamma distribution are used for $\mu_{i}$ and $\sigma_{i}$, respectively. We estimate the transition probabilities using conjugate beta priors, but use weak priors for the transition probabilities in order to avoid frequent changes in regimes. The results are generated with 10,000 iterations after 10,000 burn-in iterations. For detailed explanations, see Kim and Nelson (1999) and Hwang and Satchell (2010).

22) The estimation results are not different from the value weighted return or the equally weighted market return with securities stocks.

23) The statistics in panel $\mathrm{B}$ of $<$ Table $2>$ are not exactly the same as those of the estimation results explained above, because the regimes in panel $\mathrm{B}$ of $<$ Table $2>$ are identified with the smoothed probabilities that are larger than 0.5 . 
An Analysis of Herding in the Korean Stock Market Using Network Theory

〈Figure 4〉 Probability of Regimes

We identify bull and bear markets using the following simple regime switching model:

$$
\begin{aligned}
& r_{m t}=\mu_{1} S_{1 t}+\mu_{2} S_{2 t}+\sigma_{t} \varepsilon_{t}, \\
& \sigma_{t}=\sigma_{1} S_{1 t}+\sigma_{2} S_{2 t},
\end{aligned}
$$

Where $r_{m t}$ is the market return, $\mu_{i}$ and $\sigma_{i}$ are the expected market return and volatility of regime $i=1,2$, respectively, and the dummy (state) variable, $S_{i t}$, is one when regime $i$ is selected, and zero otherwise. As in Hamilton (1989), the state variables are assumed to be governed by a first-order Markov chain. The regime switching model is estimated using the Bayesian Markov Chain Monte Carlo Gibbs sampling estimation. The standard conju gate Gaussian distribution and the inverted gamma distribution are used for $\mu_{i}$ and $\sigma_{i}$, re ${ }^{-}$ spectively. We estimate the transition probabilities using conjugate beta priors, but use weak priors for the transition probabilities in order to avoid frequent changes in regimes. The results are generated with 10,000 iterations after 10,000 burn-in iterations. Once the two states are identified, they are labelled according to the characteristics of the expected market return and volatility.

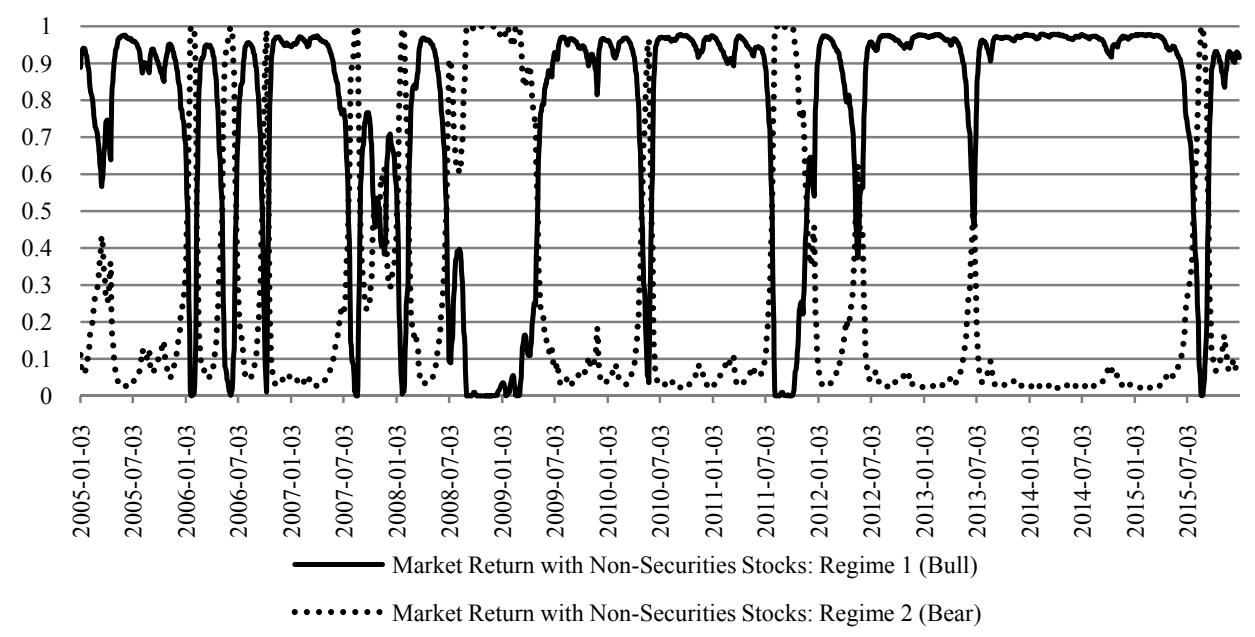

〈Table 2〉 The Properties of Cross-Sectional Dispersion of Returns

The table report the properties of cross-sectional dispersion of returns with all stocks, without securities stocks, and industries. Each cluster identified by the MST and the heuristic method requires at least 6 peripheral stocks connected to a core stock. Bull and bear states are estimated with smoothed probabilities of the regime switching model in (8). The numbers of observations in bull and bear states in panel B are slightly different from those in panels $\mathrm{A}$ and $\mathrm{C}$ because the states in panel $\mathrm{B}$ are estimated with a market index return excluding securities stocks.

A: Network with All Stocks

\begin{tabular}{rrrrrrrr}
\hline Market States & & Mean (\%) & Median (\%) & S.D. (\%) & Skewness & Kurtosis & Observation \\
\hline \multirow{4}{*}{ Entire } & $C S D_{t}$ & 2.8304 & 2.7266 & 0.6183 & 1.9722 & 12.1348 & 2,730 \\
& $C S D_{t}^{C}$ & 2.2923 & 2.0292 & 1.0655 & 1.9079 & 8.5038 & 2,730 \\
& ${ }^{C S D} D_{t}^{P}$ & 3.6135 & 3.3793 & 1.0248 & 1.9426 & 9.0125 & 2,730 \\
& $r_{m t}$ & 0.0375 & 0.162 & 1.2248 & -1.5736 & 17.2866 & 2,730 \\
\hline
\end{tabular}


한국증권학회지 제47권 3호 (2018)

〈Table 2〉 The Properties of Cross-Sectional Dispersion of Returns (Continued)

\begin{tabular}{|c|c|c|c|c|c|c|c|}
\hline \multicolumn{2}{|l|}{ Market States } & \multirow{2}{*}{$\frac{\text { Mean }(\%)}{2.7101}$} & \multirow{2}{*}{$\frac{\text { Median }(\%)}{2.6352}$} & \multirow{2}{*}{$\begin{array}{c}\text { S.D. }(\%) \\
0.5233\end{array}$} & \multirow{2}{*}{$\frac{\text { Skewness }}{2.1256}$} & \multirow{2}{*}{$\begin{array}{c}\text { Kurtosis } \\
16.7386\end{array}$} & \multirow{2}{*}{$\frac{\text { Observation }}{2,230}$} \\
\hline \multirow{4}{*}{ Bull States } & $C S D_{t}$ & & & & & & \\
\hline & $\operatorname{CSD}_{t}^{C}$ & 2.1402 & 1.9235 & 0.95 & 2.1563 & 10.9747 & 2,230 \\
\hline & $\operatorname{CSD}_{t}^{P}$ & 3.432 & 3.2478 & 0.8765 & 2.096 & 10.8448 & 2,230 \\
\hline & $r_{m t}$ & 0.0983 & 0.1831 & 0.7867 & -0.7357 & 5.0758 & 2,230 \\
\hline \multirow{4}{*}{ Bear States } & $C S D_{t}$ & 3.3667 & 3.2159 & 0.7173 & 1.7767 & 8.5571 & 500 \\
\hline & $\operatorname{CSD}_{t}^{C}$ & 2.9705 & 2.7149 & 1.27 & 1.2819 & 4.8851 & 500 \\
\hline & $\operatorname{CSD}_{t}^{P}$ & 4.4231 & 4.2181 & 1.2276 & 1.5316 & 6.2307 & 500 \\
\hline & $r_{m t}$ & -0.234 & 0.0495 & 2.3128 & -0.8366 & 6.6792 & 500 \\
\hline
\end{tabular}

B: Network with Non-Securities Stocks

\begin{tabular}{|c|c|c|c|c|c|c|c|}
\hline Market States & Variables & Mean $(\%)$ & Median (\%) & S.D. $(\%)$ & Skewness & Kurtosis & Observation \\
\hline \multirow{4}{*}{ Entire } & $C S D_{t}$ & 2.848 & 2.7460 & 0.6193 & 2.0179 & 12.6593 & 2,730 \\
\hline & $\operatorname{CSD}_{t}^{C}$ & 2.4406 & 2.2725 & 0.8438 & 1.8633 & 11.2467 & 2,730 \\
\hline & $\operatorname{CSD}_{t}^{P}$ & 3.6703 & 3.4967 & 0.8817 & 1.8513 & 10.503 & 2,730 \\
\hline & $r_{m t}$ & 0.0378 & 0.1702 & 1.2052 & -1.6176 & 17.632 & 2,730 \\
\hline \multirow{4}{*}{ Bull States } & $C S D_{t}$ & 2.7291 & 2.6601 & 0.5276 & 2.2367 & 18.134 & 2,218 \\
\hline & $\operatorname{CSD}_{t}^{C}$ & 2.3154 & 2.1802 & 0.7463 & 2.099 & 16.143 & 2,218 \\
\hline & $\operatorname{CSD}_{t}^{P}$ & 3.5072 & 3.3815 & 0.7529 & 1.9260 & 13.229 & 2,218 \\
\hline & $r_{m t}$ & 0.1057 & 0.1906 & 0.7639 & -0.7439 & 5.0754 & 2,218 \\
\hline \multirow{4}{*}{ Bear States } & $C S D_{t}$ & 3.3631 & 3.2159 & 0.7166 & 1.7471 & 8.4064 & 512 \\
\hline & $\operatorname{CSD}_{t}^{C}$ & 2.9831 & 2.8432 & 1.0116 & 1.2412 & 5.4666 & 512 \\
\hline & $\operatorname{CSD}_{t}^{P}$ & 4.377 & 4.2145 & 1.0376 & 1.6100 & 7.6349 & 512 \\
\hline & $r_{m t}$ & -0.2564 & 0.008 & 2.2624 & -0.8345 & 6.7840 & 512 \\
\hline
\end{tabular}

C: Grouping by Industry

\begin{tabular}{|c|c|c|c|c|c|c|c|}
\hline Market States & Variables & Mean $(\%)$ & Median (\%) & S.D. $(\%)$ & Skewness & Kurtosis & Observation \\
\hline \multirow{4}{*}{ Entire } & $C S D_{t}$ & 2.8304 & 2.7266 & 0.6183 & 1.9722 & 12.1348 & 2,730 \\
\hline & $\operatorname{CSD}_{t}^{C}$ & 0.7273 & 0.6719 & 0.2672 & 2.3075 & 15.5731 & 2,730 \\
\hline & $\operatorname{CSD}_{t}^{P}$ & 2.7295 & 2.6296 & 0.5855 & 2.0388 & 13.2437 & 2,730 \\
\hline & $r_{m t}$ & 0.0375 & 0.162 & 1.2248 & -1.5736 & 17.2866 & 2,730 \\
\hline \multirow{4}{*}{ Bull States } & $C S D_{t}$ & 2.7101 & 2.6352 & 0.5233 & 2.1256 & 16.7386 & 2,230 \\
\hline & $\operatorname{CSD}_{t}^{C}$ & 0.6874 & 0.6451 & 0.2291 & 2.5895 & 24.7884 & 2,230 \\
\hline & $\operatorname{CSD}_{t}^{P}$ & 2.616 & 2.5526 & 0.4998 & 2.3171 & 19.6243 & 2,230 \\
\hline & $r_{m t}$ & 0.0983 & 0.1831 & 0.7867 & -0.7357 & 5.0758 & 2,230 \\
\hline \multirow{4}{*}{ Bear States } & $C S D_{t}$ & 3.3667 & 3.2159 & 0.7173 & 1.7767 & 8.5571 & 500 \\
\hline & $\operatorname{CSD}_{t}^{C}$ & 0.9052 & 0.8176 & 0.3426 & 1.54 & 5.972 & 500 \\
\hline & $\operatorname{CSD}_{t}^{P}$ & 3.2354 & 3.0934 & 0.667 & 1.7762 & 8.7321 & 500 \\
\hline & $r_{m t}$ & -0.234 & 0.0495 & 2.3128 & -0.8366 & 6.6792 & 500 \\
\hline
\end{tabular}


An Analysis of Herding in the Korean Stock Market Using Network Theory

For comparison purposes, we also calculate the cross-sectional dispersion of industry returns with respect to market returns, and cross-sectional dispersion of individual stock returns with respect to their industry returns, which are also denoted as $\mathrm{CSD}_{t}^{C}$ and $\operatorname{CSD}_{t}^{P}$, respectively. When the CSD is estimated using industry classifications as in Chang, Cheng, and Khorana (2000), Park (2011), Kim and Choe (2012), and $\operatorname{Kim}$ (2013), the cross-sectional dispersion at the industry level, $\operatorname{CSD}_{t}^{P}$, is the aggregated CSD of all industries:

$$
\operatorname{CSD}_{t}^{P}=\sqrt{\sum_{c i=1}^{N_{c}} w_{c i} \frac{1}{N_{c i}} \sum_{i=1}^{N_{c i}}\left(r_{i t}-r_{c i t}\right)^{2}}=\sqrt{\sum_{j i=1}^{N_{j}} w_{j i} C S V_{t}^{P_{j}}}
$$

where $\operatorname{CSV}_{t}^{P_{j}}=\frac{1}{N_{j i}} \sum_{i=1}^{N_{j i}}\left(r_{i t}-r_{j i t}\right)^{2}$ for industry $j$ and $N_{j i}$ is the number of stocks in industry j. As in Yao, Ma, and He (2014), Gebka and Wohar (2013), and Demirer, Lien, and Zhang (2015), if herding arises at the industry level, $\operatorname{CSD}_{t}^{P}$ decreases when the market is under stress.

$<$ Table $2>$ reports the basic statistical properties of $\mathrm{CSD}_{t}, \mathrm{CSD}_{t}^{C}, \mathrm{CSD}_{t}^{P}$, and the stock market returns $\left(r_{m t}\right)$, whose dynamics are shown in <Figure $5>$. There is little difference in the properties of cross-sectional dispersions between when all stocks are used and when securities stocks are excluded. When securities stocks are excluded, panel $\mathrm{B}$ of $<$ Table $2>$ shows that daily averages of the cross-sectional dispersions of core stocks $\left(\mathrm{CSD}_{t}^{C}\right)$ and peripheral stocks $\left(\mathrm{CSD}_{t}^{P}\right)$ are $2.44 \%$ and $3.67 \%$, respectively. The average $\operatorname{CSD}_{t}^{C}$ and $\operatorname{CSD}_{t}^{P}$ are $2.32 \%$ and $3.51 \%$ in bull states, but increase to $2.98 \%$ and $4.38 \%$ in bear states, respectively. Thus, the cross-sectional dispersions of core stocks and peripheral stocks increase during bearish markets. These results indicate that core stocks are less dispersed than peripheral stocks, and that the dispersion increases when the market is in stress. Panel $\mathrm{C}$ shows similar patterns in $\mathrm{CSD}_{t}^{C}$ and $\operatorname{CSD}_{t}^{P}$ for industry-sorted groups, but $\operatorname{CSD}_{t}^{C}$ is much smaller than $\operatorname{CSD}_{t}^{P}$ because equally weighted industry returns are used rather than returns of a core stock. However, the difference in the unconditional cross-sectional dispersions does not necessarily indicate herding during bull markets. According to Christie and Huang (1995), herding arises when investors are under stress such that they follow others giving up their own private information. We investigate this in the following subsection. 


\section{〈Figure 5〉 Dynamics of the Cross-Sectional Dispersions}

The figure shows the dynamics of cross-sectional dispersions as in equations (4)-(6). $\mathrm{CSD}(\mathrm{P})$ represents cross-sectional dispersion (standard deviation) of peripheral stock returns with respect to their core stock returns (panels A and B) or the industry returns (panel C), and CSD(C) represents cross-sectional dispersion of core stock returns (panels $\mathrm{A}$ and $\mathrm{B}$ ) or the industry returns (panel C) with respect to the market return.

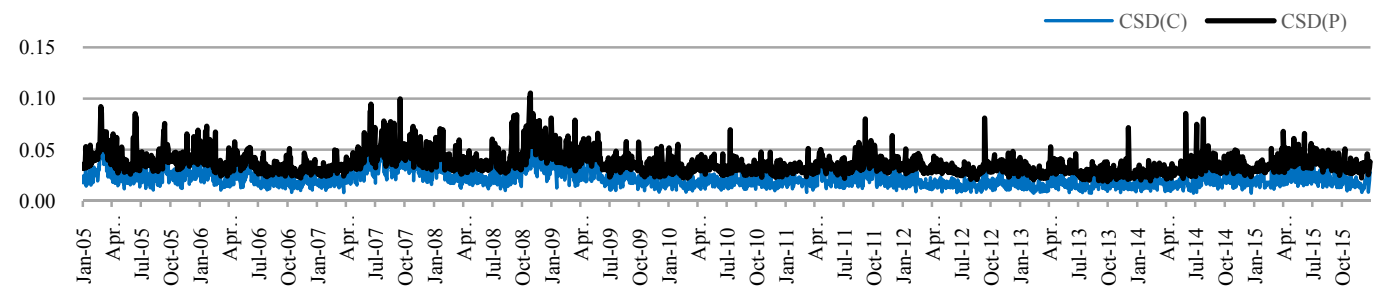

B: Cross-Sectional Dispersion with Non-securities Stocks

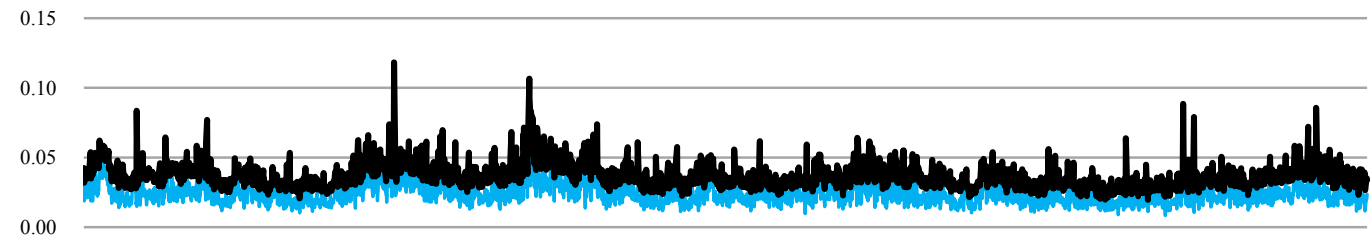

C: Cross-Sectional Dispersion by Industry

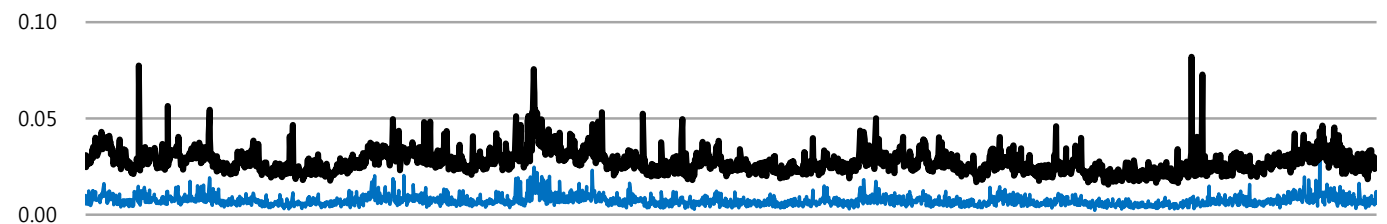

\subsection{Herding within Connected Stocks}

Herding is investigated using Equation (7). If investors herd when the market is volatile, then the coefficients on $r_{m t}^{2}$ should be negative, because the CSD decreases as investors follow returns of core stocks at extreme market movements. The effects of herding on the coefficients of $r_{m t}^{2}$ would increase further during bear states when investors are under stress.

$<$ Table 3> reports the regression results of CSDs for the entire, bull and bear periods, using the clusters with all stocks, non-securities stocks, and industries. Bull and bear states are identified by the smoothed probability in <Figure $4>$ $\left(\operatorname{prob}\left(S_{i t}\right) \geq 0.5\right)$. In all cases, the coefficients on the absolute market return are all positive and significant. This result is consistent with a close association of market vola- 
tility and cross-sectional dispersion in returns (Hwang and Satchell, 2005). In this subsection we first discuss our main results, i.e., herding within connected stocks.

The results in panel $\mathrm{B}$ of $<$ Table $3>$ show evidence of herding when investors are under stress. During bear states, the coefficients on $r_{m t}^{2}$ are all negative, and in particular, $\gamma_{2}^{+}$are significant regardless of core or peripheral stocks. On the other hand, in bull states, all coefficients on $r_{m t}^{2}$ are positive though none of them are significant. The difference between bull and bear states support the notion of Christie and Huang (1995): when investors are under stress, they follow others as volatility increases.

\section{$\langle$ Table 3〉 The Effects of Extreme Market Returns on Cross-Sectional Dispersion}

The table reports the regression results of the following equation:

$$
\mathrm{CSD}_{t}=\gamma_{0}+\gamma_{1}^{+}\left|r_{m t}\right| I_{r_{m t} \geq 0}+\gamma_{1}^{-}\left|r_{m t}\right|\left(1-I_{r_{m t} \geq 0}\right)+\gamma_{2}^{+} r_{m t}^{2} I_{r_{m t} \geq 0}+\gamma_{2}^{-} r_{m t}^{2}\left(1-I_{r_{m t} \geq 0}\right)+\varphi \operatorname{CSD}_{t-1}+\varepsilon_{t}
$$

where $\mathrm{CSD}_{t}$ is estimated using all stocks, core stocks, and peripheral stocks, and $I_{r_{m t} \geq 0}$ is an indicator variable that is one when $r_{m t} \geq 0$ and zero otherwise. For the results in panel C, core stocks are replaced by industry returns, and peripheral stocks are stocks included in each of the industries. Each clusters identified by the MST and the heuristic method requires at least 6 peripheral stocks connected to a core stock. Bull and bear states are estimated with smoothed probabilities of the regime switching model in (8). The numbers in the round brackets represent heteroskedasticity robust t-statistics.

A: Network with All Stocks

\begin{tabular}{|c|c|c|c|c|c|c|c|}
\hline & $\gamma_{0}$ & $\gamma_{1}^{+}$ & $\gamma_{1}^{-}$ & $\gamma_{2}^{+}$ & $\gamma_{2}$ & $\varphi$ & Adj $R^{2}$ \\
\hline \multicolumn{8}{|c|}{ Entire Period } \\
\hline$C S D_{t}$ & $\begin{array}{r}0.011 \\
(10.472)\end{array}$ & $\begin{array}{r}0.179 \\
(5.823)\end{array}$ & $\begin{array}{r}0.282 \\
(9.360)\end{array}$ & $\begin{array}{r}-1.505 \\
(-2.338)\end{array}$ & $\begin{array}{r}-0.368 \\
(-0.734)\end{array}$ & $\begin{array}{r}0.555 \\
(14.862)\end{array}$ & 0.549 \\
\hline $\operatorname{CSD}_{t}^{C}$ & $\begin{array}{r}0.011 \\
(14.932)\end{array}$ & $\begin{array}{r}0.561 \\
(7.244)\end{array}$ & $\begin{array}{r}0.430 \\
(7.452)\end{array}$ & $\begin{array}{r}-4.138 \\
(-2.076)\end{array}$ & $\begin{array}{r}-1.208 \\
(-1.386)\end{array}$ & $\begin{array}{r}0.367 \\
(11.643)\end{array}$ & 0.300 \\
\hline $\operatorname{CSD}_{t}^{P}$ & $\begin{array}{r}0.016 \\
(14.657) \\
\end{array}$ & $\begin{array}{r}0.500 \\
(7.282) \\
\end{array}$ & $\begin{array}{r}0.483 \\
(9.290) \\
\end{array}$ & $\begin{array}{r}-3.801 \\
(-2.183) \\
\end{array}$ & $\begin{array}{l}-1.156 \\
(-1.47) \\
\end{array}$ & $\begin{array}{r}0.451 \\
(14.794) \\
\end{array}$ & 0.432 \\
\hline \multicolumn{8}{|c|}{ Bull Period } \\
\hline$C S D_{t}$ & $\begin{array}{r}0.012 \\
(8.773)\end{array}$ & $\begin{array}{r}0.039 \\
(0.815)\end{array}$ & $\begin{array}{r}0.167 \\
(3.698)\end{array}$ & $\begin{array}{r}6.007 \\
(2.043)\end{array}$ & $\begin{array}{r}3.560 \\
(2.077)\end{array}$ & $\begin{array}{r}0.535 \\
(10.871)\end{array}$ & 0.371 \\
\hline $\operatorname{CSD}_{t}^{C}$ & $\begin{array}{r}0.012 \\
(15.598)\end{array}$ & $\begin{array}{r}0.000 \\
(0.002)\end{array}$ & $\begin{array}{r}0.236 \\
(2.426)\end{array}$ & $\begin{array}{c}31.909 \\
(3.166)\end{array}$ & $\begin{array}{r}2.995 \\
(0.670)\end{array}$ & $\begin{array}{r}0.355 \\
(9.681)\end{array}$ & 0.203 \\
\hline$C S D_{t}^{P}$ & $\begin{array}{r}0.017 \\
(14.912) \\
\end{array}$ & $\begin{array}{r}0.031 \\
(0.280) \\
\end{array}$ & $\begin{array}{r}0.282 \\
(3.441) \\
\end{array}$ & $\begin{array}{r}26.159 \\
(3.087) \\
\end{array}$ & $\begin{array}{r}4.440 \\
(1.206) \\
\end{array}$ & $\begin{array}{r}0.440 \\
(12.650) \\
\end{array}$ & 0.296 \\
\hline \multicolumn{8}{|c|}{ Bear Period } \\
\hline$C S D_{t}$ & $\begin{array}{r}0.012 \\
(6.011)\end{array}$ & $\begin{array}{r}0.171 \\
(3.337)\end{array}$ & $\begin{array}{r}0.272 \\
(5.282)\end{array}$ & $\begin{array}{r}-1.572 \\
(-1.746)\end{array}$ & $\begin{array}{r}-0.384 \\
(-0.519)\end{array}$ & $\begin{array}{r}0.538 \\
(9.506)\end{array}$ & 0.676 \\
\hline $\operatorname{CSD}_{t}^{C}$ & $\begin{array}{r}0.013 \\
(6.585)\end{array}$ & $\begin{array}{r}0.546 \\
(4.356)\end{array}$ & $\begin{array}{r}0.394 \\
(3.882)\end{array}$ & $\begin{array}{r}-4.519 \\
(-2.072)\end{array}$ & $\begin{array}{r}-1.002 \\
(-0.773)\end{array}$ & $\begin{array}{r}0.349 \\
(5.495)\end{array}$ & 0.329 \\
\hline $\operatorname{CSD}_{t}^{P}$ & $\begin{array}{r}0.020 \\
(6.029)\end{array}$ & $\begin{array}{r}0.470 \\
(4.021)\end{array}$ & $\begin{array}{r}0.441 \\
(4.673)\end{array}$ & $\begin{array}{r}-3.772 \\
(-1.745)\end{array}$ & $\begin{array}{r}-0.868 \\
(-0.709)\end{array}$ & $\begin{array}{r}0.410 \\
(5.890)\end{array}$ & 0.463 \\
\hline
\end{tabular}


한국증권학회지 제47권 3호 (2018)

$\langle$ Table 3〉 The Effects of Extreme Market Returns on Cross-Sectional Dispersion (Continued) B: Network with Non-Securities Stocks

\begin{tabular}{|c|c|c|c|c|c|c|c|}
\hline & $\gamma_{0}$ & $\gamma_{1}^{+}$ & $\gamma_{1}^{-}$ & $\gamma_{2}^{+}$ & $\gamma_{2}^{-}$ & $\varphi$ & Adj $R^{2}$ \\
\hline \multicolumn{8}{|c|}{ Entire Period } \\
\hline$C S D_{t}$ & $\begin{array}{r}0.011 \\
(10.389)\end{array}$ & $\begin{array}{r}0.168 \\
(5.528)\end{array}$ & $\begin{array}{r}0.283 \\
(9.385)\end{array}$ & $\begin{array}{r}-1.410 \\
(-2.375)\end{array}$ & $\begin{array}{r}-0.371 \\
(-0.747)\end{array}$ & $\begin{array}{r}0.548 \\
(14.167)\end{array}$ & 0.534 \\
\hline $\operatorname{CSD}_{t}^{C}$ & $\begin{array}{r}0.013 \\
(17.870)\end{array}$ & $\begin{array}{r}0.363 \\
(6.073)\end{array}$ & $\begin{array}{r}0.317 \\
(7.316)\end{array}$ & $\begin{array}{r}-2.671 \\
(-2.076)\end{array}$ & $\begin{array}{r}-0.280 \\
(-0.436)\end{array}$ & $\begin{array}{r}0.380 \\
(13.708)\end{array}$ & 0.299 \\
\hline $\operatorname{CSD}_{t}^{P}$ & $\begin{array}{r}0.016 \\
(15.244) \\
\end{array}$ & $\begin{array}{r}0.321 \\
(6.650) \\
\end{array}$ & $\begin{array}{r}0.400 \\
(9.658) \\
\end{array}$ & $\begin{array}{r}-2.652 \\
(-2.964) \\
\end{array}$ & $\begin{array}{l}-0.724 \\
(-1.19) \\
\end{array}$ & $\begin{array}{r}0.504 \\
(18.291) \\
\end{array}$ & 0.469 \\
\hline \multicolumn{8}{|c|}{$\overline{\text { Bull Period }}$} \\
\hline$C S D_{t}$ & $\begin{array}{r}0.012 \\
(8.757)\end{array}$ & $\begin{array}{r}0.044 \\
(0.846)\end{array}$ & $\begin{array}{r}0.180 \\
(3.666)\end{array}$ & $\begin{array}{r}5.376 \\
(1.664)\end{array}$ & $\begin{array}{r}3.120 \\
(1.630)\end{array}$ & $\begin{array}{r}0.525 \\
(10.365)\end{array}$ & 0.354 \\
\hline $\operatorname{CSD}_{t}^{C}$ & $\begin{array}{r}0.013 \\
(16.507)\end{array}$ & $\begin{array}{r}0.133 \\
(1.468)\end{array}$ & $\begin{array}{r}0.239 \\
(3.257)\end{array}$ & $\begin{array}{r}8.537 \\
(1.407)\end{array}$ & $\begin{array}{r}0.168 \\
(0.063)\end{array}$ & $\begin{array}{r}0.371 \\
(10.867)\end{array}$ & 0.177 \\
\hline $\operatorname{CSD}_{t}^{P}$ & $\begin{array}{r}0.016 \\
(13.618) \\
\end{array}$ & $\begin{array}{r}0.131 \\
(1.649) \\
\end{array}$ & $\begin{array}{r}0.284 \\
(3.994) \\
\end{array}$ & $\begin{array}{r}7.924 \\
(1.522) \\
\end{array}$ & $\begin{array}{r}2.628 \\
(0.972) \\
\end{array}$ & $\begin{array}{r}0.490 \\
(14.311) \\
\end{array}$ & 0.311 \\
\hline \multicolumn{8}{|c|}{ Bear Period } \\
\hline$C S D_{t}$ & $\begin{array}{r}0.012 \\
(6.216)\end{array}$ & $\begin{array}{r}0.157 \\
(3.237)\end{array}$ & $\begin{array}{r}0.268 \\
(5.312)\end{array}$ & $\begin{array}{r}-1.487 \\
(-1.817)\end{array}$ & $\begin{array}{r}-0.343 \\
(-0.464)\end{array}$ & $\begin{array}{r}0.545 \\
(9.946)\end{array}$ & 0.672 \\
\hline $\operatorname{CSD}_{t}^{C}$ & $\begin{array}{r}0.015 \\
(7.974)\end{array}$ & $\begin{array}{r}0.407 \\
(4.600)\end{array}$ & $\begin{array}{r}0.297 \\
(4.164)\end{array}$ & $\begin{array}{r}-3.482 \\
(-2.472)\end{array}$ & $\begin{array}{r}-0.161 \\
(-0.179)\end{array}$ & $\begin{array}{r}0.339 \\
(6.484)\end{array}$ & 0.356 \\
\hline $\operatorname{CSD}_{t}^{P}$ & $\begin{array}{r}0.018 \\
(6.769)\end{array}$ & $\begin{array}{r}0.309 \\
(3.999)\end{array}$ & $\begin{array}{r}0.364 \\
(5.051)\end{array}$ & $\begin{array}{r}-2.703 \\
(-2.187)\end{array}$ & $\begin{array}{r}-0.465 \\
(-0.491)\end{array}$ & $\begin{array}{r}0.469 \\
(8.355)\end{array}$ & 0.538 \\
\hline \multicolumn{8}{|c|}{ C: Grouping by Industry } \\
\hline & $\gamma_{0}$ & $\gamma_{1}^{+}$ & $\gamma_{1}^{-}$ & $\gamma_{2}^{+}$ & $\gamma_{2} \overline{2}$ & $\varphi$ & Adj $\mathrm{R}^{2}$ \\
\hline \multicolumn{8}{|c|}{ Entire Period } \\
\hline$C S D_{t}$ & $\begin{array}{r}0.011 \\
(10.472)\end{array}$ & $\begin{array}{r}0.179 \\
(5.823)\end{array}$ & $\begin{array}{r}0.282 \\
(9.360)\end{array}$ & $\begin{array}{r}-1.505 \\
(-2.338)\end{array}$ & $\begin{array}{r}-0.368 \\
(-0.734)\end{array}$ & $\begin{array}{r}0.555 \\
(14.862)\end{array}$ & 0.549 \\
\hline $\operatorname{CSD}_{t}^{C}$ & $\begin{array}{r}0.004 \\
(18.671)\end{array}$ & $\begin{array}{r}0.144 \\
(7.054)\end{array}$ & $\begin{array}{r}0.128 \\
(8.446)\end{array}$ & $\begin{array}{r}-0.733 \\
(-1.247)\end{array}$ & $\begin{array}{r}-0.040 \\
(-0.158)\end{array}$ & $\begin{array}{r}0.313 \\
(12.430)\end{array}$ & 0.350 \\
\hline $\operatorname{CSD}_{t}^{P}$ & $\begin{array}{r}0.011 \\
(9.672) \\
\end{array}$ & $\begin{array}{r}0.149 \\
(5.461) \\
\end{array}$ & $\begin{array}{r}0.261 \\
(9.335) \\
\end{array}$ & $\begin{array}{r}-1.300 \\
(-2.582) \\
\end{array}$ & $\begin{array}{r}-0.393 \\
(-0.881) \\
\end{array}$ & $\begin{array}{r}0.557 \\
(13.545) \\
\end{array}$ & 0.536 \\
\hline \multicolumn{8}{|c|}{ Bull Period } \\
\hline$C S D_{t}$ & $\begin{array}{r}0.012 \\
(8.773)\end{array}$ & $\begin{array}{r}0.039 \\
(0.815)\end{array}$ & $\begin{array}{r}0.167 \\
(3.698)\end{array}$ & $\begin{array}{r}6.007 \\
(2.043)\end{array}$ & $\begin{array}{r}3.560 \\
(2.077)\end{array}$ & $\begin{array}{r}0.535 \\
(10.871)\end{array}$ & 0.371 \\
\hline $\operatorname{CSD}_{t}^{C}$ & $\begin{array}{r}0.004 \\
(21.031)\end{array}$ & $\begin{array}{r}0.023 \\
(0.741)\end{array}$ & $\begin{array}{r}0.083 \\
(3.417)\end{array}$ & $\begin{array}{r}5.810 \\
(2.607)\end{array}$ & $\begin{array}{r}0.828 \\
(0.840)\end{array}$ & $\begin{array}{r}0.335 \\
(13.112)\end{array}$ & 0.195 \\
\hline $\operatorname{CSD}_{t}^{P}$ & $\begin{array}{r}0.012 \\
(8.179) \\
\end{array}$ & $\begin{array}{r}0.038 \\
(0.826) \\
\end{array}$ & $\begin{array}{r}0.151 \\
(3.499) \\
\end{array}$ & $\begin{array}{r}4.453 \\
(1.573) \\
\end{array}$ & $\begin{array}{r}3.494 \\
(2.144) \\
\end{array}$ & $\begin{array}{r}0.530 \\
(9.843) \\
\end{array}$ & 0.358 \\
\hline \multicolumn{8}{|c|}{ Bear Period } \\
\hline$C S D_{t}$ & $\begin{array}{r}0.012 \\
(6.011)\end{array}$ & $\begin{array}{r}0.171 \\
(3.337)\end{array}$ & $\begin{array}{r}0.272 \\
(5.282)\end{array}$ & $\begin{array}{r}-1.572 \\
(-1.746)\end{array}$ & $\begin{array}{r}-0.384 \\
(-0.519)\end{array}$ & $\begin{array}{r}0.538 \\
(9.506)\end{array}$ & 0.676 \\
\hline $\operatorname{CSD}_{t}^{C}$ & $\begin{array}{r}0.005 \\
(7.556)\end{array}$ & $\begin{array}{r}0.176 \\
(5.634)\end{array}$ & $\begin{array}{r}0.137 \\
(5.494)\end{array}$ & $\begin{array}{r}-1.099 \\
(-1.853)\end{array}$ & $\begin{array}{r}-0.121 \\
(-0.349)\end{array}$ & $\begin{array}{r}0.227 \\
(3.729)\end{array}$ & 0.467 \\
\hline $\operatorname{CSD}_{t}^{P}$ & $\begin{array}{r}0.011 \\
(5.944)\end{array}$ & $\begin{array}{r}0.129 \\
(2.842)\end{array}$ & $\begin{array}{r}0.247 \\
(5.211)\end{array}$ & $\begin{array}{r}-1.282 \\
(-1.716)\end{array}$ & $\begin{array}{r}-0.394 \\
(-0.592)\end{array}$ & $\begin{array}{r}0.558 \\
(9.860)\end{array}$ & 0.671 \\
\hline
\end{tabular}


However, the evidence of herding during bear states is stronger when market returns are positive than negative. As in Bikhchandani and Sharma (2001) and Baumeister et al. (2001), if investors follow others at large and negative market returns and thus herding increases due to investors' panic behavior under stress, then we expect $\gamma_{2}^{-}<\gamma_{2}^{+}<0$. However, our results show $\gamma_{2}^{+}<\gamma_{2}^{-}$although herding arises in bear states. Note that it is not a small number of negative returns during bear markets that derive herding. ${ }^{24)}$

How can we explain the unexpected results, i.e., herding arises for positive market returns during bear markets? We propose an explanation based on an asymmetric response of overconfident investors to market-wide signals. It is well documented that investors become overconfident when their prior expectation is reinforced by signals because of self-attribution bias (Daniel, Hirshleifer, and Subrahmanyam, 1998, 2001). This type of overconfidence is asymmetric because overconfidence arises only when priors are consistent with signals. In bear states when stock prices are low and thus the expected market return is high, overconfident investors would over-react to positive signals because their high prior expected returns are reinforced by positive signals. Recently, Hwang and Salmon (2017) model this type of herding in asset returns when overconfident investors over-respond to market-wide signals. Because of this type of self-attribution bias of overconfident investors, individual stock returns would increase in a similar way regardless of their fundamentals, decreasing the cross-sectional dispersion in returns. ${ }^{25)}$ In other words, herd behavior does not necessarily arise simply because investors are in panic, but can be observed when investors have a strong consensus (i.e., overconfidence) on the market outlook. ${ }^{26)}$

\subsection{Herding within Connected Stocks Including Securities Stocks or within Industries}

Are the main results in the previous subsection different from what is already well documented in the literature? In this subsection we answer this question by comparing the main results with two other cases in <Table 3>: clusters with all stocks (including securities stocks) and industry classification.

24) Among the 512 days of bear markets, the numbers of days of positive and negative market returns are 257 and 255 respectively, and the average daily returns are $1.33 \%$ and $-1.86 \%$, respectively. For comparison, among the 2,218 days of bull markets, the numbers of days of positive and negative market returns are 1,341 and 877 respectively, and the average daily returns are $0.57 \%$ and $-0.61 \%$, respectively.

25 ) Note that this is not about the effects of overconfidence how overconfident investors respond to signals about individual stocks, not about the overall market.

26) Empirical tests are above the scope of this study. We leave this for a future study. 
When bull and bear states are disregarded, the regression results of the CSD show evidence of herding: all coefficients, $\gamma_{2} \mathrm{~s}$, are negative and, in particular, $\gamma_{2}^{+}$are significant regardless of core or peripheral stocks (market or industry). These results suggest that investors follow others during large market movements and confirms that herd behavior exists in the Korean stock market as in Chang, Cheng, and Khorana (2000), Park (2011), Kim and Choe (2012), and Kim (2013).

However, herding in the entire period may be misleading because asymmetric responses of CSDs to $r_{m t}^{2}$ in different market states are disregarded. Panel $\mathrm{C}$ of $<$ Table $3>$ shows weak statistical evidence of herding in bear states when the industry is used to group stocks: the coefficients on $r_{m t}^{2}$ are negative only at the $10 \%$ significance level. It is only when market states are disregarded that the results for the entire period show evidence of herding.

A more interesting result is the positive coefficients on $r_{m t}^{2}$ in panels A and C, indicating 'adverse herding' in bull states. The adverse herding is stronger when market returns are positive rather than negative. Individual stock returns are less likely to follow the market consensus or core stocks during large positive market movements in bull states.

The result can be interpreted as follows. When returns are on average positive and volatility is low, investors are relaxed (opposite to investor stress in bear states). They are less likely to pay attention to the market or core stocks (industry) but instead they use their own signals such that stock returns are far more crosssectionally dispersed. Large positive market returns in bull states allow investors to trade without considering too much about the consequences of their trading. On the other hand, herding during bear states can be interpreted as investor behavior that takes too much into their consideration about the overall market movement (Hwang and Salmon, 2017).

\subsection{Further Interpretation of the Results}

Our results are interpreted that herding arises because investors trade stocks by following the movements of connected stocks in bear states. The difference between panels B and C comes from how the clusters are identified. Because the MST method groups individual stocks using correlation in returns, each cluster includes highly correlated stocks. When investors buy or sell certain stocks under stress, they can observe returns of other stocks that are highly correlated with the stocks they want to trade. When investors are under stress in bear states, then they are likely to trade following these other connected stocks suppressing their own private information. Then herding arises. 
These connected stocks may belong to the same industry, or may be stocks that have similar characteristics, e.g., size or book-to-market ratio regardless of industry. The connections in returns (return correlation) are better captured by the MST method than by industry, and thus the results in panel B can be interpreted that investors herd by observing the returns of connected stocks. If market and industry returns are the only two components that can capture the connections in returns, ${ }^{27)}$ then there should be little difference between the results in panels B and C. The difference in fact indicates that there exist other connections in returns that are not captured by industry.

The difference between panels A and B is whether or not securities (brokerage) stocks are included in the network. The network identified with all stocks may not represent connections between non-securities stocks, because it is dominated by the 25 securities stocks <Table 1>. Moreover, for investors who try to sell stocks in a sector, the returns of securities stocks may not be of their concerns. They may be more interested in the returns in the same sector or the returns of firms with similar size or boot-to-market ratio. Securities firms hold huge amount of other stocks and thus connections in returns would not be informative for investors.

\subsection{Robustness of Results}

The robustness of our results are tested in several ways. First, the results of Equation (9) reported in <Table $4>$ are consistent with the findings in <Table $3>$. In all cases, the coefficients on the absolute market return are all positive and significant. Herding occurs in bear states, whereas adverse herding is observed in bull markets. The difference in coefficients between bull and bear states is significant in all cases: the null hypothesis $\mathrm{H}_{0}: \gamma_{2 u}^{+}=\gamma_{2 d}^{+}$is rejected at the $5 \%$ significance level.

Second, our results are robust to different minimum numbers of peripheral stocks connected to a core stock. We set $K=5$ and 7 instead of 6 , and investigate herding for core and peripheral stocks, as described above. When the minimum numbers of peripheral stocks connected to a core stock are set to 5 and 7 , the numbers of clusters become 36 and 18 for all stocks and 42 and 20 for non-securities stocks, respectively. Note that when $\mathrm{K}=6$, that the numbers of clusters are 28 for all stocks and 36 for non-securities stocks. As expected, the number of core stocks increases when the minimum number of clusters decreases. The results of Equation (7) when $K=5$ and 7

which are reported in <Table $5>$ are consistent with those in <Table $3>$. Herding arises in bear states and adverse herding is observed only when securities stocks are included. Otherwise, we do not find evidence of adverse herding.

27) For example, see Campbell, Lettau, Malkiel, and $\mathrm{Xu}$ (2001). 


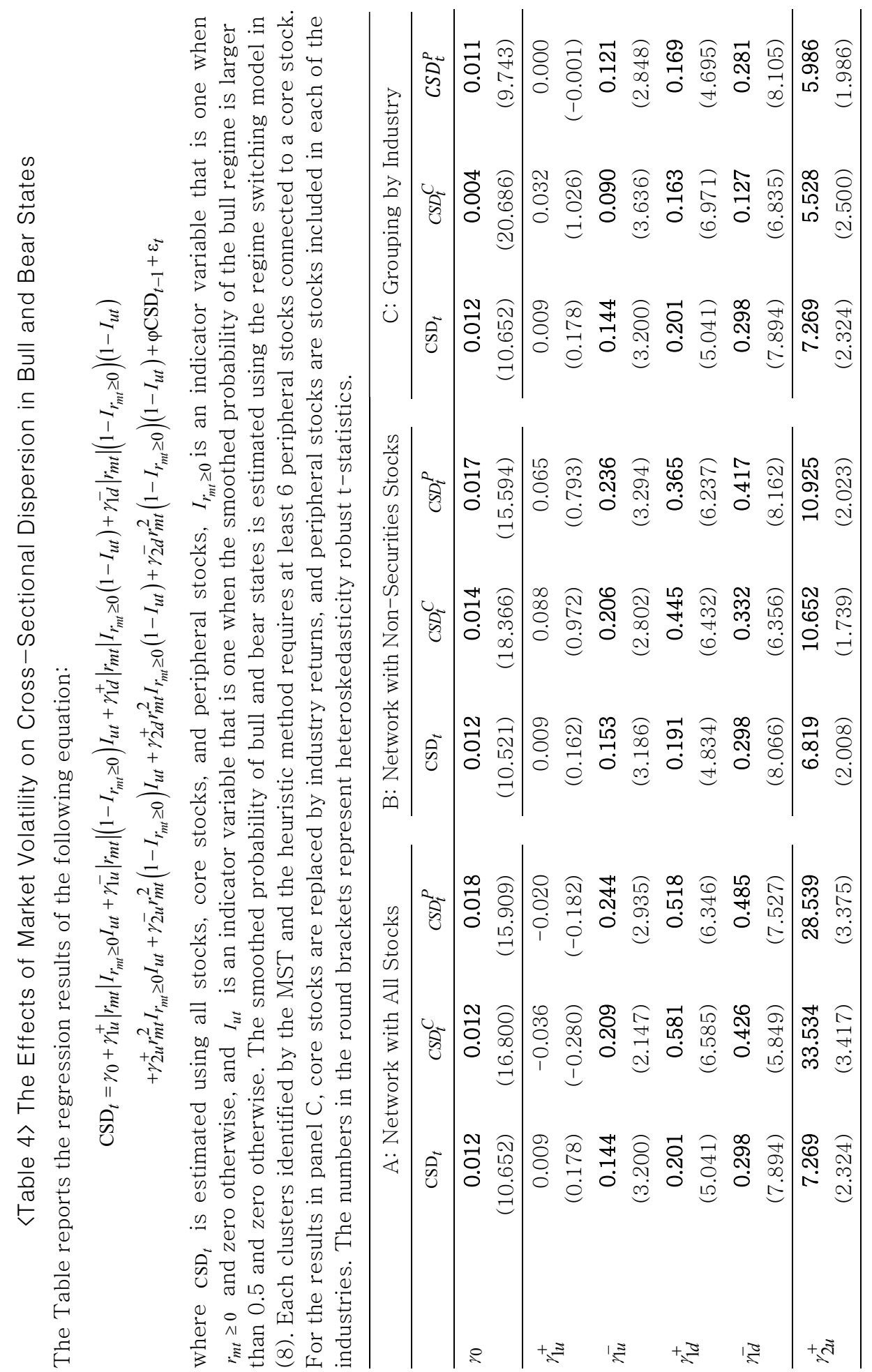




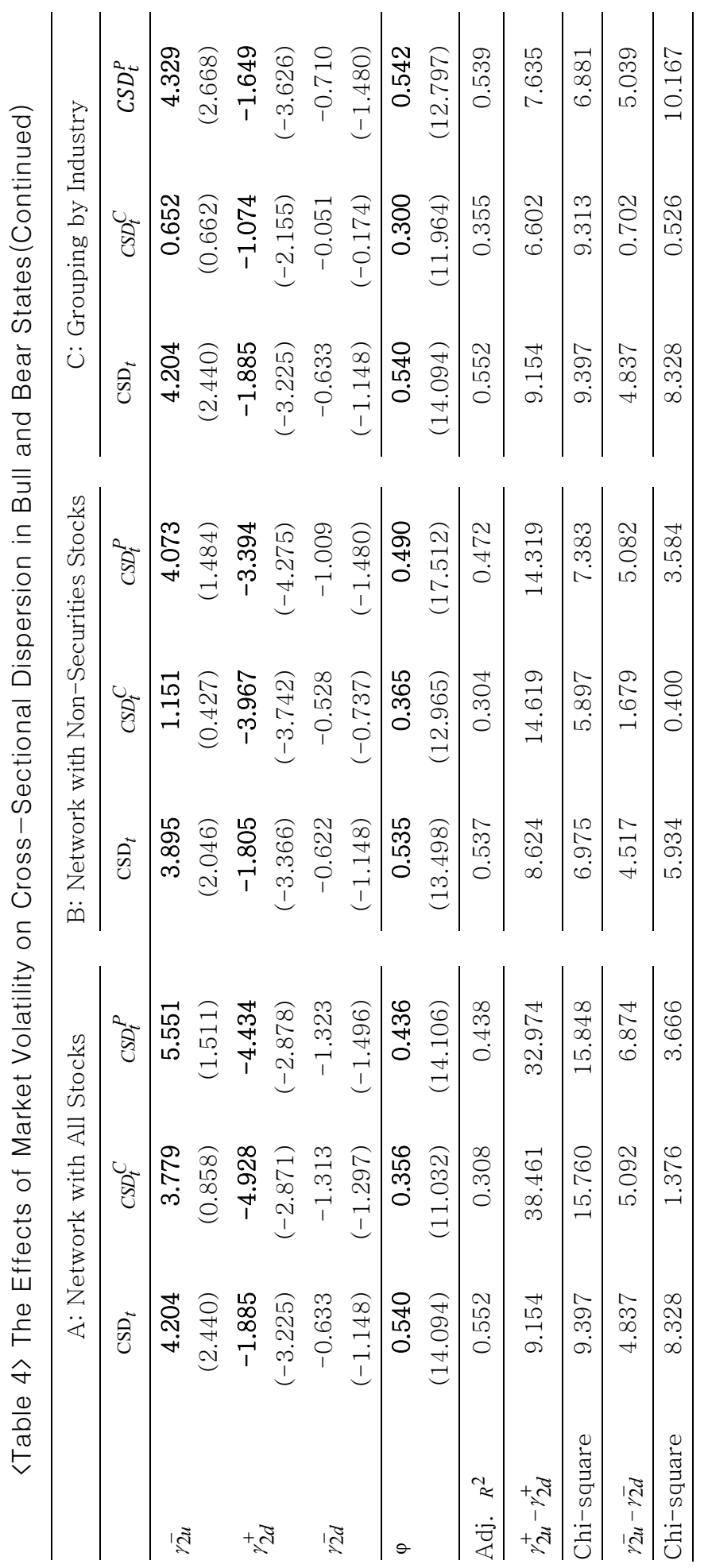




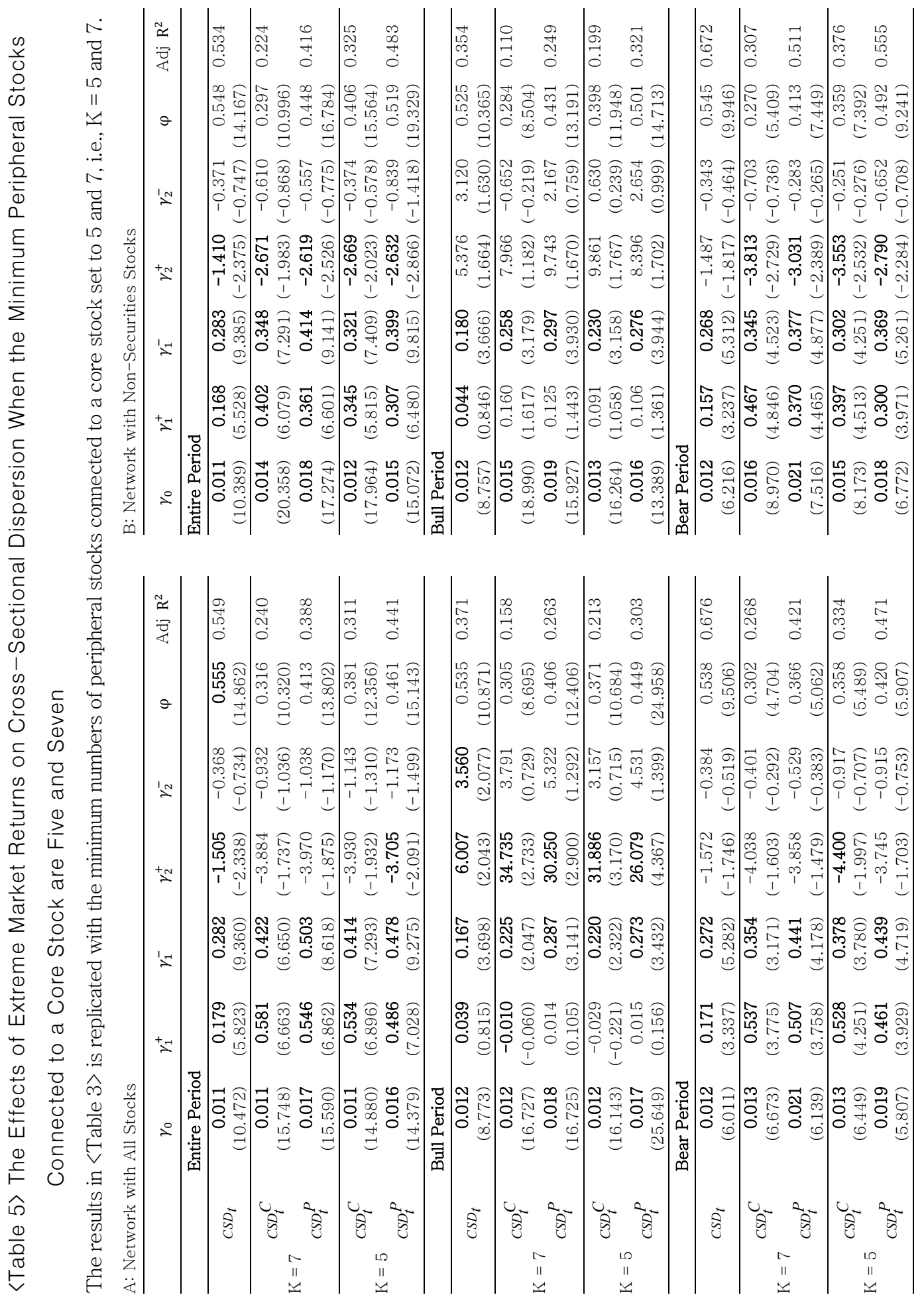


An Analysis of Herding in the Korean Stock Market Using Network Theory

Third, Chang, Chen, and Khorana (2000) propose cross-sectional absolute deviation $\left(\mathrm{CSAD}_{t}=\frac{1}{N-1} \sum_{i=1}^{N}\left|r_{i t}-r_{m t}\right|\right)$ to capture the non-linear relation between stock return dispersions and the market return. For robustness of our results, we calculate $\mathrm{CSAD}_{t}$ for all stocks with respect to the market return, $C S A D_{t}^{C}$ for peripheral stocks with respect to core stocks and $C S A D_{t}^{P}$ for core stocks with respect to the market, which are corresponding to $\mathrm{CSD}_{t}, C S D_{t}^{C}$, and $C S D_{t}^{P}$, respectively. The results with crosssectional absolute deviation using non-financial stocks in $<$ Table $6>$ are similar to those with cross-sectional standard deviation in $<$ Table $3>$ and $<$ Table $4>$. Herding arises in bear states when market returns are positive.

〈Table 6> The Effects of Market Volatility on Cross-Sectional Absolute Deviation in Bull and Bear States

The table reports the regression results of the following equation:

$$
\begin{aligned}
\mathrm{CSAD}_{t}= & \gamma_{0}+\gamma_{1 u}^{+}\left|r_{m t}\right| I_{r_{m t} \geq 0} I_{u t}+\gamma_{1 u}^{-}\left|r_{m t}\right|\left(1-I_{r_{m t} \geq 0}\right) I_{u t}+\gamma_{1 d}^{+}\left|r_{m t}\right| I_{r_{m t} \geq 0}\left(1-I_{u t}\right)+\gamma_{1 d}^{+}\left|r_{m t}\right| I_{r_{m t} \geq 0}\left(1-I_{u t}\right) \\
& +\gamma_{1 d}^{-}\left|r_{m t}\right|\left(1-I_{r_{m t} \geq 0}\right)\left(1-I_{u t}\right)+\gamma_{2 u}^{+} r_{m t}^{2} I_{r_{m t} \geq 0} I_{u t}+\gamma_{2 u}^{-} r_{m t}^{2}\left(1-I_{r_{m t} \geq 0}\right) I_{u t}+\gamma_{2 d}^{+} r_{m t}^{2} I_{r_{m t} \geq 0}\left(1-I_{u t}\right) \\
& +\gamma_{2}^{-} r_{m t}^{2}\left(1-I_{r_{m t} \geq 0}\right)\left(1-I_{u t}\right)+\varphi \mathrm{CSAD}_{t-1}+\varepsilon_{t},
\end{aligned}
$$

where $\operatorname{CSAD}_{t}$ is estimated using all non-financial stocks, core stocks, and peripheral stocks, $I_{r_{m t} \geq 0}$ is an indicator variable that is one when $r_{m t} \geq 0$ and zero otherwise, and $I_{u t}$ is an indicator variable that is one when the smoothed probability of the bull regime is larger than 0.5 and zero otherwise. The smoothed probability of bull and bear states is estimated using the regime switching model in (8). Each clusters identified by the MST and the heuristic method requires at least 6 peripheral stocks connected to a core stock. The numbers in the round brackets represent heteroskedasticity robust t-statistics.

Network with Non- Securities Stocks

\begin{tabular}{lrrr}
\hline & $\operatorname{CSAD}_{t}$ & ${ }^{c}$ & $\operatorname{CSAD}_{t}^{C}$ \\
\hline$\gamma_{0}$ & 0.006 & 0.009 & 0.010 \\
& $(13.449)$ & $(16.029)$ & $(16.768)$ \\
\hline$\gamma_{1 u}^{+}$ & 0.099 & 0.090 & 0.122 \\
& $(3.018)$ & $(1.452)$ & $(2.118)$ \\
$\gamma_{1 \bar{u}}$ & 0.176 & 0.209 & 0.225 \\
& $(6.748)$ & $(4.320)$ & $(4.750)$ \\
$\gamma_{1 d}^{+}$ & 0.178 & 0.316 & 0.333 \\
& $(6.171)$ & $(6.380)$ & $(6.156)$ \\
$\gamma_{1} \bar{d}$ & 0.255 & 0.284 & 0.363 \\
& $(7.377)$ & $(7.239)$ & $(6.876)$ \\
\hline$\gamma_{2 u}^{+}$ & 2.948 & 5.876 & 5.170 \\
& $(1.425)$ & $(1.428)$ & $(1.423)$ \\
\hline
\end{tabular}


〈Table 6〉 The Effects of Market Volatility on Cross-Sectional Absolute Deviation in Bull and Bear States (Continued)

\begin{tabular}{lrrr}
\hline & $\operatorname{CSAD}_{t}$ & $\operatorname{CSAD}_{t}^{C}$ & $\operatorname{CSAD}_{t}^{P}$ \\
\hline$\gamma_{\overline{2} u}$ & 2.359 & 0.244 & 2.312 \\
& $(2.280)$ & $(0.135)$ & $(1.306)$ \\
$\gamma_{2 d}^{+}$ & -1.699 & -2.481 & -3.763 \\
& $-(3.674)$ & -3.120 & $-(4.641)$ \\
$\gamma_{\overline{2} d}$ & -0.120 & -0.156 & -1.120 \\
& -0.191 & -0.266 & -1.361 \\
\hline$\varphi$ & 0.614 & 0.415 & 0.546 \\
\hline Adj. $R^{2}$ & $(26.616)$ & $(14.405)$ & 0.604 \\
\hline$\gamma_{2 u}^{+}-\gamma_{2 d}^{+}$ & 0.781 & 0.434 & 8.933 \\
\hline Chi-square & 4.646 & 8.357 & 6.708 \\
\hline$\gamma_{\overline{2} u}-\gamma_{2} d$ & 5.831 & 4.364 & 3.433 \\
\hline Chi-square & 2.479 & 0.399 & 4.119 \\
\hline
\end{tabular}

Finally, we also use dummy variables for the extreme upper or lower tails may not capture herding in the market. For example, when $\mathrm{CSD}_{t}$ or $\mathrm{CSAD}_{t}$ is regressed on the two dummies $D_{t}^{U}$ and $D_{t}^{L}$ for the bottom $5 \%$ and the top $5 \%$, respectively, none of the coefficients are negative (the numbers in the brackets represent heteroskedasticityrobust standard errors).

$$
\begin{aligned}
\mathrm{CSD}_{t} & =\underset{(10.081)}{0.0011}+\underset{(3,855)}{0.0017} D_{t}^{U}+\underset{(10.784)}{0.0073} D_{t}^{L}+\underset{(14.751)}{0.5881 \mathrm{CSD}_{t-1}+\varepsilon_{t},} \\
\mathrm{CSAD}_{t} & =\underset{(12.585)}{0.0054}+\underset{(5.524)}{0.0016} D_{t}^{U}+\underset{(11.276)}{0.0066} D_{t}^{L}+\underset{(29.129)}{0.6922 \mathrm{CSAD}_{t-1}}+\varepsilon_{t} .
\end{aligned}
$$

These results support Chang, Cheng, and Khorana (2000) that Christie and Huang (1995) would not capture herding when non-linearity between the cross-sectional return dispersion and the market return is weak.

\section{Conclusions}

In this study, we analyze networks in the Korean stock market using the minimum spanning tree algorithm, and then, investigate if herd behavior is led by a small sample of 'core' stocks or by 'peripheral' stocks during bear states in the stock market. Using cross-sectional dispersions of core stocks and of peripheral stocks, we show that herding arises for both core stocks and peripheral stocks during bear 
states.

We also find a few interesting asymmetric features of herding during bull and bear market states. First, during bull states, we find adverse herding, i.e., that the CSDs increase at extreme market movements. Adverse herding appears to be mainly driven by securities firms because it is significant only when networks with all stocks or industry are used for grouping. Second, both core stocks and peripheral stocks exhibit herding in bear market states. However, it is noteworthy that herding exhibited in bear states is significant when the stock market rises.

Our study suggests that co-movements in asset returns should be analyzed using networks identified with connections in returns rather than the conventional grouping method such as industries. This is because stock returns in an industry are not necessarily highly correlated with each other, and because there are many other links that connect stocks returns even across industries. The patterns of return comovements show us a different story when the connections are identified with correlations and analyzed using network theory.

Based on the network theory, we identify a significant interdependence between core and peripheral stocks in each core cluster, and assume that herding arises between these clustered stocks. Recent studies propose methods that include directions to investigate the spill-over effects in financial markets (Billio, Getmansky, Lo, and Pelizzon, 2012; Diebold and Yilmaz, 2012, 2016). These studies identify directions using Granger causality. An application of these techniques to hundreds of individual stocks would not be easy but certainly is an interesting topic. We leave this for future study.

Our results involving Long-term Orientation show, contrary to prior literature, that it relates negatively to dividend smoothing. In a highly long-term oriented culture, we conclude, managers as well as shareholders are patient for future profits from risky investments, rather than importunate for immediate dividend pay-ins. Finally, we tested Hofstede's sixth culture variable (IVR) for its effect on dividend smoothing, and it turns out to relate positively to it. We conclude that, in a highly indulgent culture, immediate gratification from smooth dividends is more important than turbulent or curtailed dividends for perseverance cause. 


\section{References}

Anton, M. and C. Polk, 2014, Connected Stocks, Journal of Finance 69 (3), pp. 10991127.

Ahn, D., J. S. Conrad, and R. F. Dittmar, 2009, Basis Assets, Review of Financial Studies 22 (12), pp. 5133-5174.

Banerjee, A., 1992, A Simple Model of Herd Behavior, Quarterly Journal of Economics 107 (3), pp. 797-817.

Barber, B. M., T. Odean, and N. Zhu, 2009, Do Retail Trades Move Markets?, Review of Financial Studies 22 (1), pp. 151-186.

Batagelj, V., 2003, Efficient algorithms for citation network analysis, Available from: http://arxiv.org/ · abs/cs.DL/0309023.

Baumeister, R. F., E. Bratslavsky, C. Finkenauer, and K. D. Vohs, 2001, Bad is stronger than good, Review of general psychology 5 (4), pp. 323-370.

Bikhchandani, S., D. Hirshleifer, and I. Welch, 1992, A Theory of Fads, Fashion, Custom and Cultural Change as Informational Cascades, Journal of Political Economy 100 (5), pp. 992-1026.

Bikhchandani, S. and S. Sharma, 2001, Herd Behavior in Financial Markets, IMF Staff Paper 47 (3), pp. 279-310.

Billio, M., M. Getmansky, A. Lo, and L. Pelizzon, 2012, Econometric measures of connectedness and systemic risk in the finance and insurance sectors, Journal of Financial Economics 104 (3), pp. 535-559.

Boyd, D. M. and N. B. Ellison, 2007, Social Network Sites: Definition, History and Scholarship, Journal of Computer-Mediated Communication 13 (1), Article 1.

Brunnermeier, M. K., 2001, Asset pricing under asymmetric information: Bubbles, crashes, technical analysis, and herding, Oxford University Press on Demand.

Campbell, J. Y., M. Lettau, B. G. Malkiel, and Y. Xu, 2001, Have Individual Stocks Become More Volatile? An Empirical Exploration of Idiosyncratic Risk, Journal of Finance 56 (1), pp. 1-43.

Chang, C. H. and S. J. Lin, 2015, The effect of national culture and pitfalls on investors' decision-making: Herding behavior in international stock market, International Review of Economics and Finance 37, pp. 380-392.

Chang, E. C., J. W. Cheng, and A. Khorana, 2000, An examination of herd behavior in equity markets: an international perspective, Journal of Banking and Finance 24 (10), pp. 1651-1679.

Chen, T., 2013, Do Investors Herd in Global Stock Markets?, Journal of Behavioral Finance 14 (3), pp. 230-239. 
An Analysis of Herding in the Korean Stock Market Using Network Theory

Choi, N. and R. W. Sias, 2009, Institutional industry herding, Journal of Financial Economics 94 (3), pp. 469-491.

Christie, W. G. and R. D. Huang, 1995, Following the pied piper: Do individual returns herd around the market?, Financial Analysts Journal 51 (4), pp. 31-37.

Cipriani, M. and A. Guarino, 2014, Estimating a Structural Model of Herd Behavior in Financial Markets, American Economic Review 104 (1), pp. 224-251.

Cormen, T. H., C. E. Leiserson, R. L. Rivest, and C. Stein, 2009, Introduction to Algorithms, MIT Press.

Coval, J. and E. Stafford, 2007, Asset fire sales (and purchases) in equity markets, Journal of Financial Economics 86 (2), pp. 479-512.

Daniel, K., D. Hirshleifer, and A. Subrahmanyam, 1998, Investor psychology and security market under-and overreactions, Journal of Finance 53 (6), pp. 1839-1885.

Daniel, K., D. Hirshleifer, and A. Subrahmanyam, 2001, Overconfidence, arbitrage, and equilibrium asset pricing, Journal of Finance 56 (3), pp. 921-965.

Demirer, R., D. Lien, and H. Zhang, 2015, Industry herding and momentum strategies, Pacific-Basin Finance Journal 32, pp. 95-110.

Diebold, F. X. and K. Yilmaz, 2012, Better to give than to receive: Predictive directional measurement of volatility spillovers, International Journal of Forecasting 28 (1), pp. 57-66.

Diebold, F. X. and K. Yilmaz, 2016, Trans-Atlantic Equity Volatility Connectedness: U.S. and European Financial Institutions, 2004-2014, Journal of Financial Econometrics 14 (1), pp. 81-127.

Dorogovtsev, S. N., J. F. Mendes, and A. N. Samukhin, 2003, Metric structure of random networks, Nuclear Physics B 653 (3), pp. 307-338.

Garlaschelli, D., S. Battiston, M. Castri, V. Servedio, and G. Caldarelli, 2005, Statistical Mechanics and its Applications 350 (2), pp. 491-499.

Gatev, E., W. N. Goetzmann, and K. G. Rouwenhorst, 2006, Pairs Trading: Performance of a Relative Value Arbitrage Rule, Yale ICF Working Paper 08-03.

Gebka, B. and M. E. Wohar, 2013, International herding: Does it differ across sectors?, Journal of International Markets, Institutions \& Money 23, pp. 55-84.

Hamilton, J. D., 1989, A New Approach to the Economic Analysis of Nonstationary Time Series and the Business Cycle, Econometrica 57 (2), pp. 357-384.

Harvey, C. R., Y. Liu, and H. Zhu, 2016, ... and the Cross-Section of Expected Returns, Review of Financial Studies 29 (1), pp. 5-68.

Hirshleifer, D. and S. H. Teoh, 2003, Herd behaviour and cascading in capital markets: A review and synthesis, European Financial Management 9 (1), pp. 25-66.

Hirshleifer, D. and S. H. Teoh, 2009, The Psychological Attraction Approach to Ac- 
counting and Disclosure Policy, Contemporary Accounting Research 26 (4), pp. 1067-1090.

Hong, H., J. Kubik, and J. C. Stein, 2004, Social Interaction and Stock-Market Participation, Journal of Finance 59 (1), pp. 137-163.

Hwang, S. and M. Salmon, 2017, Overconfidence, sentiment and beta herding, Working Paper.

Hwang, S. and S. E. Satchell, 2005, Valuing Information Using Utility Functions, European Journal of Finance 11 (1), pp. 1-16.

Hwang, S. and S. E. Satchell, 2010, How Loss Averse Are Investors in Financial Markets?, Journal of Banking and Finance 34 (10), pp. 2425-2438.

Kelly, M. and C. Ó. Gráda, 2000, Market Contagion: Evidence from the Panics of 1854 and 1857, American Economic Review 11 (5), pp. 1110-1124.

Kenett, D. Y., Y. Shapira, and E. Ben-Jacob, 2010, RMT assessments of the market latent information embedded in the stocks' raw, normalized, and partial correlations, Journal of Probability and Statistics 2009, Article ID 249370, p. 13.

Kenett, D. Y., Y. Shapira, A. Madi, S. Bransburg-Zabary, G. Gur-Gershgoren, and E. Ben-Jacob, 2010, Dynamics of stock market correlations, AUCO Czech Economic Review 4 (3), pp. 330-341.

Kenett, D. Y., M. Tumminello, A. Madi, G. Gur-Gershgoren, R. N. Mantegna, and E. Ben-Jacob, 2010, Dominating clasp of the financial sector revealed by partial correlation analysis of the stock market, PloS one 5 (12), e15032.

Kim, C. and C. R. Nelson, 1999, State-space models with regime switching, MIT Press.

Kim, J. H. and H. Choe, 2012, The herding behavior of professionals and its impact in the Korean stock market, Asian Review of Financial Studies 41 (3), pp. 463-495.

Kim, S. H., 2013, Empirical Tests of Herding Behavior in the Korean Stock Market, Hankook Gyungje Youngu 31 (3), pp. 117-144.

Kruskal, J. B., 1956, On the Shortest Spanning Subtree of a Graph and the Traveling Salesman Problem, Proceedings of the American Mathematical Society 7 (1), pp. 48-50.

Lakonishok, J., A. Shleifer, and R. W. Vishny, 1992, The impact of institutional trading on stock prices, Journal of Financial Economics 32 (1), pp. 23-43.

Lee, Y. J. and G. Woo, 2013, Analysis of the Stock Market Network for Portfolio Recommendation, Journal of Digital Contents Society 13 (11), pp. 48-58.

Mantegna, R. N., 1999, Hierachical structure in financial markets, European Physical Journal B 11 (1), pp. 193-197.

Naylor, M. J., L. C. Rose, and B. J. Moyle, 2007, Topology of foreign exchange markets using hierarchical structure methods, Physica A: Statistical Mechanics and its Applications 382 (1), pp. 199-208. 
An Analysis of Herding in the Korean Stock Market Using Network Theory

Onnela, J. P., A. Chakraborti, K. Kaski, J. Kertesz, and A. Kanto, 2003a, Dynamics of market correlations: Taxonomy and portfolio analysis, Physical Review E. 68 (5), pp. 056110.

Onnela, J. P., A. Chakraborti, K. Kaski, J. Kertesz, and A. Kanto, 2003b, Asset trees and asset graphs in financial markets, Physica Scripta (T106), 48.

Park, B. J., 2011, Herd Behavior and Volatility in Financial Markets, Journal of the Korean data and information science society 22 (6), pp. 1199-1215.

Peeters, G. and J. Czapinski, 1990, Positive-negative asymmetry in evaluations: The distinction between affective and informational negativity effects, European Review of Social Psychology 1 (1), pp. 33-60.

Raafat, R. M., N. Chater, and C. Frith, 2009, Herding in humans, Trends in Cognitive Sciences 13 (10), pp. 420-428.

Schwert, G. W., 1990, Stock volatility and the crash of 87 , Review of financial Studies 3 (1), pp. 77-102.

Schwert, G. W., 1990, Stock returns and real activity: A century of evidence, The Journal of Finance 45 (4), pp. 1237-57.

Scott, J., 2012, Social network analysis, Page 19.

Shleifer, A. and R. W. Vishny, 1992, Liquidation Value and Debt Capacity: A Market Equilibrium Approach, Journal of Finance 47 (4), pp. 1343-1366.

Tumminello, M., T. Aste, T. Di Matteo, and R. N. Mantegna, 2005, A tool for filtering information in complex systems, Proceedings of the National Academy of Sciences of the United States of America 102 (30), pp. 10421-6.

Tumminello, M., F. Lillo, and R. N. Mantegna, 2010, Correlation, hierarchies, and networks in financial markets, Journal of Economic Behavior \& Organization 75 (1), pp. 40-58.

Welch, I., 1992, Sequential Sales, Learning and Cascades, Journal of Finance 47 (2), pp. 695-732.

Welch, I., 2000, Herding among security analysts, Journal of Financial Economics 58 (3), pp. 369-396.

Wermers, R., 1999, Mutual Fund Herding and the Impact on Stock Prices, Journal of Finance 54 (2), pp. 581-622.

Yao, J., C. Ma, and W. P. He, 2014, Investor herding behavior of Chinese stock market, International Review of Economics and Finance 29, pp. 12-29.

Zellner, A., 1971, An introduction to Bayesian inference in econometrics, New York: Wiley. 


\section{$<$ Appendix $>$}

Using core and peripheral stocks, we decompose the CSV into two parts, crosssectional variance of core stocks and cross-sectional variance of peripheral stocks, as follows:

$$
\begin{aligned}
C S V_{t} & =\frac{1}{N} \sum_{i=1}^{N}\left(r_{i t}-r_{m t}\right)^{2} \\
& =\frac{1}{N} \sum_{i=1}^{N}\left(r_{i t}-r_{c i t}\right)^{2}+\frac{1}{N} \sum_{i=1}^{N}\left(r_{c i t}-r_{m t}\right)^{2}+\frac{2}{N} \sum_{i=1}^{N}\left(r_{i t}-r_{c i t}\right)\left(r_{c i t}-r_{m t}\right) \\
& =\frac{1}{N} \sum_{c i=1}^{N_{c}} \sum_{i=1}^{N_{c i}}\left(r_{i t}-r_{c i t}\right)^{2}+\frac{1}{N} \sum_{c i=1}^{N_{c}} N_{c i}\left(r_{c i t}-r_{m t}\right)^{2} \\
& =\sum_{c i=1}^{N_{c}} w_{c i} \frac{1}{N_{c i}} \sum_{i=1}^{N_{c i}}\left(r_{i t}-r_{c i t}\right)^{2}+\sum_{c i=1}^{N_{c}} w_{c i}\left(r_{c i t}-r_{m t}\right)^{2}
\end{aligned}
$$

assuming $\frac{2}{N-1} \sum_{i=1}^{N}\left(r_{i t}-r_{c i t}\right)\left(r_{c i t}-r_{m t}\right)=0$, where $r_{c i t}$ denotes a core stock return, $N_{c}$ and $N_{c i}$ represent the numbers of core stocks and their peripheral stocks linked to core stock $c$, respectively, and $w_{c i}=\frac{N_{c i}}{N}$. The first component represents the weighted average cross-sectional variance of peripheral stocks linked to core stocks, whereas the second component represents the weighted cross-sectional variance of core stocks to the market. 


\title{
네트워크이론을 이용한 한국주식시장의 군집행동 분석*
}

\author{
황 수 성 (성균관대학교) \\ 김 영 일 (성균관대학교) \\ 신 진 호 (성균관대학교)**
}

본 연구에서는 주식시장의 스트레스 상황 하에서 투자자들이 기업의 본질가치 변화나 소속된 산업의 움직임 보다는 네트워크 상에서 밀접하게 '연결된 주식'의 가격변화를 추종하는지 여부를 네트워크 이론으로 분석한다. 실증분석 결과, 2005년 1월부터 2015년 12월까지의 기간 동안 한국주식시장에서 군집행동이 나타났으며, 이는 기존의 문헌과도 일치하는 결과이다. 흥미로운 점은 시장이 불황기일 때 군집행동은 주가가 상승하는 경우에 나타난다는 것이다. 이러한 결과는 과신하는 투자자들이 가격 상승이라는 긍정적인 신호에 대해 과민반응하는 것으로 해석할 수 있다. 왜냐하면, 시장이 불황일 때는 현재시점의 가격이 낮기 때문에 투자자의 기대수익률이 높은데, 이 때 긍정적인 신호가 나타난다면 이 신호는 높은 수익률을 기대했던 투자자들의 사전적인 믿음과 일치하는 것이므로 자기귀인편향(self-attribution bias)을 유발시키기 때문이다. 반면, 시장 불황기에서 주가가 급락하는 경우에는 군집행동이 항상 나타나지는 않았다.

핵심 단어: 군집행동, 네트워크, 국면전환, 과신, 연결된 주식

JEL 분류기호: G01, D85

* 본 논문의 내용에 대해 유익한 조언을 해 주신 2016년 재무금융관련 5 개학회 학술발표회 참석자들과 성균관대학교 경제학과 교수 및 학생들께 감사드립니다.

** 연락담당 저자, 주소: 서울특별시 종로구 성균관로 25-2 성균관대학교 경영대학 03063; E-mail: jinho.shinn@gmail.com; Tel: 02-3788-2334; Fax: 02-3788-2350. 